\title{
Phase Transformation Dynamics in Sulfate-Loaded Lanthanide Triphosphonates. Proton Conductivity and Application as Fillers in PEMFCs
}

Inés R. Salcedo, ${ }^{\dagger}$ Rosario M. P. Colodrero, ${ }^{\dagger}$ Montse Bazaga-García, M. López-González, Carmen del Río, Konstantinos Xanthopoulos, Konstantinos D. Demadis, Gary B. Hix, Aleksandra D. Furasova, Duane Choquesillo-Lazarte, Pascual Olivera-Pastor,* and Aurelio Cabeza*

Cite This: ACS Appl. Mater. Interfaces 2021, 13, 15279-15291 Read Online

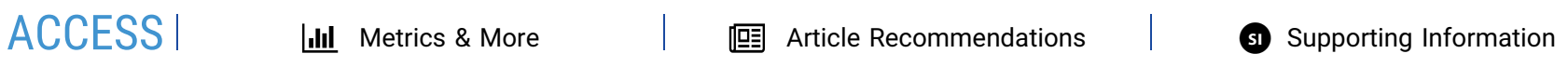

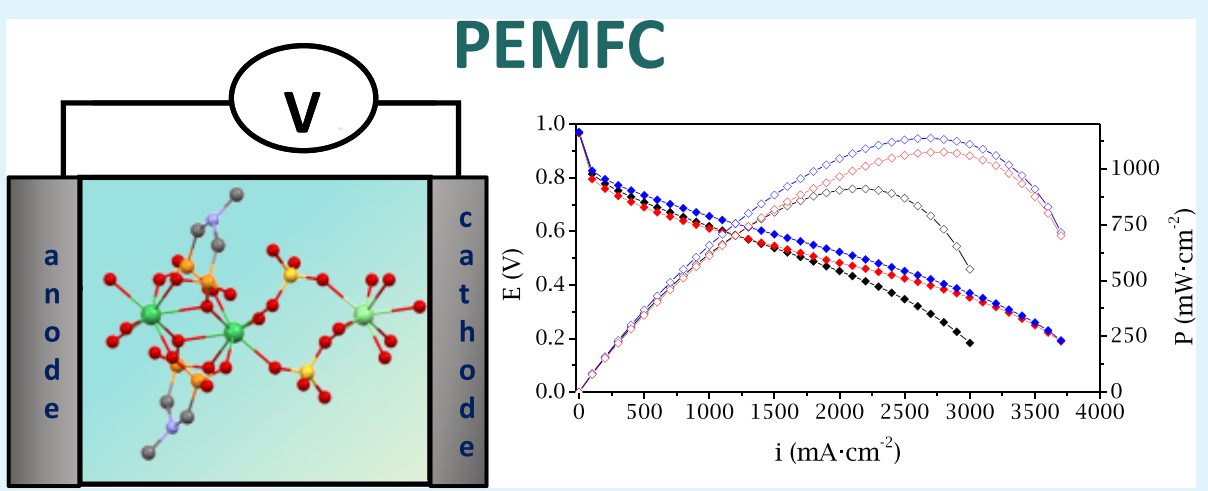

ABSTRACT: Phase transformation dynamics and proton conduction properties are reported for cationic layer-featured coordination polymers derived from the combination of lanthanide ions $\left(\mathrm{Ln}^{3+}\right)$ with nitrilo-tris(methylenephosphonic acid) $\left(\mathrm{H}_{6} \mathrm{NMP}\right)$ in the presence of sulfate ions. Two families of materials are isolated and structurally characterized, i.e., $\left[\mathrm{Ln}_{2}\left(\mathrm{H}_{4} \mathrm{NMP}\right)_{2}\left(\mathrm{H}_{2} \mathrm{O}\right)_{4}\right]\left(\mathrm{HSO}_{4}\right)_{2} \cdot n \mathrm{H}_{2} \mathrm{O}(\mathrm{Ln}=\mathrm{Pr}, \mathrm{Nd}, \mathrm{Sm}, \mathrm{Eu}, \mathrm{Gd}, \mathrm{Tb}, \mathrm{Er}, \mathrm{Yb} ; n=4-5$, Series $\mathrm{I})$ and $\left[\mathrm{Ln}\left(\mathrm{H}_{5} \mathrm{NMP}\right)\right] \mathrm{SO}$. $2 \mathrm{H}_{2} \mathrm{O}(\mathrm{Ln}=\mathrm{Pr}, \mathrm{Nd}, \mathrm{Eu}, \mathrm{Gd}, \mathrm{Tb}$; Series II). Eu/Tb bimetallic solid solutions are also prepared for photoluminescence studies. Members of families I and II display high proton conductivity $\left(10^{-3}\right.$ and $10^{-2} \mathrm{~S} \cdot \mathrm{cm}^{-1}$ at $80{ }^{\circ} \mathrm{C}$ and $95 \%$ relative humidity) and are studied as fillers for Nafion-based composite membranes in PEMFCs, under operating conditions. Composite membranes exhibit higher power and current densities than the pristine Nafion membrane working in the range of $70-90{ }^{\circ} \mathrm{C}$ and $100 \%$ relative humidity and with similar proton conductivity.

KEYWORDS: metal phosphonate, proton conductivity, composite membranes, Nafion, PEMFCs

\section{INTRODUCTION}

Up to now, Nafion has been the benchmark of polymer electrolytes. However, new advances are desirable to facilitate enhanced performance for proton exchange membrane fuel cells (PEMFCs). ${ }^{1}$ Among the various strategies implemented, ${ }^{2,3}$ incorporating or doping Nafion membranes with inorganic nanoparticles has beneficial effects on thermal stability, water uptake and/or management, and proton conductivity. In addition, Nafion-mixed membranes can provide higher power densities than the pristine Nafion membranes.

Coordination polymers (CPs) exhibit high crystallinity, ${ }^{8}$ precise proton transfer pathways, ${ }^{9}$ and a wide variety of structural architectures that depend on the metal center ${ }^{10}$ and/ or the organic linker, ${ }^{11}$ which make them attractive as potential fillers for Nafion-mixed membranes. Among the plethora of
CPs, ${ }^{12-14}$ metal phosphonate-based proton conductors hold a prominent position. ${ }^{15-19}$ In these, the organic linker contains one or more phosphonate groups $\left(-\mathrm{PO}_{3} \mathrm{H}_{x}{ }^{-(2-x)}\right.$, where $x=0$, 1 , or 2 , depending on the deprotonation degree). Moreover, organic phosphonic acid frameworks (phosphonate HOFs), with supramolecular architectures, are attractive materials due to their porosity and conductive behavior, including proton conductivity. $^{20}$

Received: January 22, 2021

Accepted: March 16, 2021

Published: March 25, 2021 
Additional advantages of metal phosphonates in comparison to other CPs are (a) increased hydrolytic stability of the $\mathrm{P}-\mathrm{C}$ and $\mathrm{M}-\mathrm{O}$ bonds, ${ }^{21}$ (b) enhanced thermal stability, ${ }^{22}$ (c) variable structures with well-defined proton conduction pathways, $^{23}$ (d) acidic sites on the ligands, ${ }^{24}$ (e) water molecules (either metal-coordinated or in the lattice) that commonly act as proton carriers, ${ }^{25}$ and (f) the ability to host anions or cations (either in channels or in the interlayer space) that may augment proton conduction. ${ }^{26,27}$ In addition, derivatizing CPs with strongly acidic groups has shown to be a highly efficient strategy for enhancing proton conductivity. $^{28,29}$

Recently, results from our collaborative effort have been published on the use of layered lanthanide CPs utilizing a phosphonate derivative of taurine (namely, 2-[bis(phosphonomethyl)amino] ethanosulfonic acid), which assists in maintaining the proton conductivity of Nafion membranes at least up to $90{ }^{\circ} \mathrm{C}$ and perform satisfactorily in PEMFC single cells. ${ }^{30}$

Combined with divalent transition metals or lanthanide-ions, nitrilo-tris (methylenephosphonic acid) $\left(\mathrm{H}_{6} \mathrm{NMP}\right)$ yields acidic bidimensional solids. ${ }^{31}$ In contrast to the divalent metal derivatives, which form neutral layers, ${ }^{31}$ lanthanide derivatives present both neutral ${ }^{32}$ and positively charge layers with interesting properties as proton conductors, catalysts, and photoluminescent materials. ${ }^{33-35}$ Moreover, the latter undergo dynamic structural transformation, as observed for [Ln$\left.\left(\mathrm{H}_{4} \mathrm{NMP}\right)\left(\mathrm{H}_{2} \mathrm{O}\right)_{2}\right](\mathrm{Cl}) \cdot 2 \mathrm{H}_{2} \mathrm{O} \quad\left[\mathrm{Ln}=\mathrm{La}^{3+}, \mathrm{Pr}^{3+}, \mathrm{Sm}^{3+}, \mathrm{Eu}^{3+}\right.$, $\left.\mathrm{Gd}^{3+}, \mathrm{Tb}^{3+}, \mathrm{Dy}^{3+}, \mathrm{Ho}^{3+}\right) .^{33-35}$ Interestingly, the $\mathrm{Gd}^{3+}$ derivative was found to convert, at high humidity and temperature, into a chloride-free compound, which demonstrated substantially enhanced proton conductivity, up to $0.51 \mathrm{~S} \cdot \mathrm{cm}^{-1} .35$

Herein, we present a detailed study in order to access to Ln$\mathrm{H}_{x} \mathrm{NMP}$ derivatives containing the proton-enhancing sulfate ion. Incorporating sulfate species into the framework of CPs can be an effective way of enhancing proton conductivity. ${ }^{36}$ Hence, we report the syntheses and structural features of several compounds as members of the growing family of lanthanide-sulfate-nitrilo(trismethylenephosphonates). These compounds display high proton conductivity values between $10^{-3}$ and $10^{-2} \mathrm{~S} \cdot \mathrm{cm}^{-1}$ at $80{ }^{\circ} \mathrm{C}$ and $95 \% \mathrm{RH}$. Selected materials have also been studied as fillers for the preparation of Nafion-mixed membranes, and their responses in proton exchange membrane fuel cells (PEMFCs) have been established under operating conditions. Preliminary studies show that the resulting composite membranes exhibit similar proton conductivity behavior and, in some cases, higher power and current densities than the pristine Nafion membrane working in the range of $70-90{ }^{\circ} \mathrm{C}$ and $100 \% \mathrm{RH}$.

\section{EXPERIMENTAL SECTION}

Materials and Instrumentation. Hydrated lanthanide nitrate or chloride reagents and $\mathrm{H}_{6} \mathrm{NMP}(50 \% \mathrm{w} / \mathrm{w}$ solution in water as acid) were purchased from Sigma-Aldrich. Sulfuric acid was from BDH Prolabo. In-house deionized (DI) water was used for all synthesis. Nafion 1100 EW dispersion 20 wt \% in a mixture of water and alcohols was purchased from Ion Power. Isopropanol was obtained from Merck \& Co. Elemental analyses (C, H, N, S) were measured on a TruSpec Macro CHN-S analyzer. Thermogravimetric analysis (TGA) data were recorded on an SDT-Q600 analyzer from TA Instruments. The temperature varied from RT to $900{ }^{\circ} \mathrm{C}$ at a heating rate of $10{ }^{\circ} \mathrm{C} / \mathrm{min}$. Measurements were carried out on samples in open platinum crucibles under a flow of air or $\mathrm{N}_{2}$. Lanthanide and phosphorus contents in solids were determined by inductively coupled plasma mass spectrometry analysis (ICP-MS).

Synthesis. Two families of sulfate-containing polymorphs were isolated depending on the specific synthesis conditions, starting from two solutions separately prepared and then mixed. The lanthanide salt $(0.46 \mathrm{mmol})$ was dissolved in DI water $(10 \mathrm{~mL})$. The ligand solution was obtained upon dilution of $\mathrm{H}_{6} \mathrm{NMP}(2.30 \mathrm{mmol}, 1.5 \mathrm{~mL})$ in DI water $(20 \mathrm{~mL})$. Compounds Series I, $\left[\operatorname{Ln}_{2}\left(\mathrm{H}_{4} \mathrm{NMP}\right)_{2}\left(\mathrm{H}_{2} \mathrm{O}\right)_{4}\right]$ $\left(\mathrm{HSO}_{4}\right)_{2} \cdot n \mathrm{H}_{2} \mathrm{O}\left(\mathrm{Ln}=\mathrm{Pr}^{3+}, \mathrm{Nd}^{3+}, \mathrm{Sm}^{3+}, \mathrm{Eu}^{3+}, \mathrm{Gd}^{3+}, \mathrm{Tb}^{3+}, \mathrm{Er}^{3+}, \mathrm{Yb}^{3+}\right.$; $n=4-5)$, or Series II, $\mathrm{Ln}[(\mathrm{HNMP})] \mathrm{SO}_{4} \cdot 2 \mathrm{H}_{2} \mathrm{O}\left(\mathrm{Ln}=\mathrm{Pr}^{3+}, \mathrm{Nd}^{3+}\right.$, $\left.\mathrm{Eu}^{3+}, \mathrm{Gd}^{3+}, \mathrm{Tb}^{3+}\right)$, were obtained by crystallization at $25{ }^{\circ} \mathrm{C}$ for several days in the presence of $\mathrm{H}_{2} \mathrm{SO}_{4}(95 \%)$ in specific amounts. Compounds of Series I required the addition of a volume of $\mathrm{H}_{2} \mathrm{SO}_{4}(95 \%)$ ranging between 0.5 and $2.5\left(\mathrm{Eu}^{3+}\right)$ to $3.5\left(\mathrm{Pr}^{3+}\right) \mathrm{mL}$. Higher volumes of $\mathrm{H}_{2} \mathrm{SO}_{4}$ (95\%) up to $5 \mathrm{~mL}$ led to Series II compounds. All attempts to extend the synthesis beyond the $\mathrm{Tb}^{3+}$ derivative were unsuccessful. Compound $\operatorname{Pr}-\mathrm{I}^{*}$ was synthesized as follows: $0.25 \mathrm{mmol}$ of $\operatorname{Pr}\left(\mathrm{NO}_{3}\right)_{3} \cdot 6 \mathrm{H}_{2} \mathrm{O}$ was dissolved in $5 \mathrm{~mL}$ of DI water and was then added to $0.217 \mathrm{~mL}$ of $\mathrm{H}_{6} \mathrm{NMP}$ aqueous solution ( $0.47 \mathrm{mmol} \mathrm{H}_{6} \mathrm{NMP}$ ). Finally, $0.5 \mathrm{~mL}$ of $\mathrm{H}_{2} \mathrm{SO}_{4}(95 \%)$ was added to the solution mixture. This solution was left to crystallize in a glass test tube at RT for several days. The obtained solids were filtered off, washed with DI water, and air-dried. Typical yields for compounds of Series I ranged between 33 and 84\%, based on the metal, for $\mathrm{Er}^{3+}$ and $\mathrm{Tb}^{3+}$ derivatives, respectively.

Elemental composition (wt \%) for compounds of Series I: Anal. calcd for $\mathrm{Pr}_{2} \mathrm{C}_{6} \mathrm{H}_{38} \mathrm{~N}_{2} \mathrm{O}_{34} \mathrm{P}_{6} \mathrm{~S}_{2}$ : C 5.94, H 3.15, N 2.31, S 5.28; found C 5.87, H 2.77, N 2.36, S 5.10. Anal. calcd for $\mathrm{Nd}_{2} \mathrm{C}_{6} \mathrm{H}_{38} \mathrm{~N}_{2} \mathrm{O}_{34} \mathrm{P}_{6} \mathrm{~S}_{2}$ : C 5.90, H 3.14, N 2.29, S 5.25; found C 5.88, H 2.99, N 2.32, S 4.98. Anal. calcd for $\mathrm{Sm}_{2} \mathrm{C}_{6} \mathrm{H}_{38} \mathrm{~N}_{2} \mathrm{O}_{34} \mathrm{P}_{6} \mathrm{~S}_{2}$ : C 5.84, H 3.11, N 2.27, S 5.20; found $\mathrm{C}$ 5.66, $\mathrm{H}$ 3.17, $\mathrm{N}$ 2.27, $\mathrm{S}$ 5.75. Anal. calcd for $\mathrm{Eu}_{2} \mathrm{C}_{6} \mathrm{H}_{38} \mathrm{~N}_{2} \mathrm{O}_{34} \mathrm{P}_{6} \mathrm{~S}_{2}$ : C 5.83, H 3.09, N 2.27, S 5.19; found C 5.46, $\mathrm{H}$ 2.91, N 2.25, S 5.02. Anal. calcd for $\mathrm{Gd}_{2} \mathrm{C}_{6} \mathrm{H}_{38} \mathrm{~N}_{2} \mathrm{O}_{34} \mathrm{P}_{6} \mathrm{~S}_{2}$ : C 5.78, $\mathrm{H}$ 3.07, N 2.25, S 5.14; found C 5.58, H 3.00, N 2.26, S 5.40. Anal. calcd for $\mathrm{Tb}_{2} \mathrm{C}_{6} \mathrm{H}_{38} \mathrm{~N}_{2} \mathrm{O}_{34} \mathrm{P}_{6} \mathrm{~S}_{2}$ : C 5.76, H 3.06, N 2.24, S 5.13; found C 5.58, H 3.00, N 2.27, S 5.18. Anal. calcd for $\mathrm{Er}_{2} \mathrm{C}_{6} \mathrm{H}_{40} \mathrm{~N}_{2} \mathrm{O}_{35} \mathrm{P}_{6} \mathrm{~S}_{2}: \mathrm{C}$ 5.61, H 3.14, N 2.18, S 4.99; found C 5.24, H 2.85, N 3.13, S 5.42. Anal. calcd for $\mathrm{Yb}_{2} \mathrm{C}_{6} \mathrm{H}_{40} \mathrm{~N}_{2} \mathrm{O}_{35} \mathrm{P}_{6} \mathrm{~S}_{2}$ : C 5.56, H 3.11, N 2.16, S 4.95; found C 5.27, H 3.37, N 2.20, S 4.49.

Elemental composition (wt \%) for compounds of Series II: Anal. calcd for $\operatorname{PrC}_{3} \mathrm{H}_{15} \mathrm{NO}_{15} \mathrm{P} 3 \mathrm{~S}$ : C 6.31, H 2.65, N 2.45, S 5.62; found $\mathrm{C}$ 5.89, $\mathrm{H}$ 2.62, N 2.42, S 5.78. Anal. calcd for $\mathrm{NdC}_{3} \mathrm{H}_{15} \mathrm{NO}_{15} \mathrm{P}_{3} \mathrm{~S}$ : C 6.27, $\mathrm{H}$ 2.63, N 2.44, S 5.58; found C 5.91, H 2.58, N 2.43, S 4.75. Anal. calcd for $\mathrm{EuC}_{3} \mathrm{H}_{15} \mathrm{NO}_{15} \mathrm{P}_{3} \mathrm{~S}$ : C 6.19, $\mathrm{H}$ 2.60, N 2.41, S 5.51; found $\mathrm{C}$ 6.09, $\mathrm{H}$ 2.70, $\mathrm{N}$ 2.54, S 5.73. Anal. calcd for $\mathrm{GdC}_{3} \mathrm{H}_{15} \mathrm{NO}_{15} \mathrm{P}_{3} \mathrm{~S}$ : C 6.13, H 2.57, N 2.38, S 5.46; found C 5.38, $\mathrm{H}$ 2.60, N 2.23, S 5.80. Anal. calcd for $\mathrm{TbC}_{3} \mathrm{H}_{15} \mathrm{NO}_{15} \mathrm{P} 3 \mathrm{~S}: \mathrm{C} 6.12, \mathrm{H}$ 2.57, N 2.38, S 5.44; found C 6.14, H 2.62, N 2.27, S 5.74.

Bimetallic solid solutions with nominal compositions $\left[\operatorname{Ln}(1)_{1.6} \mathrm{Ln}\right.$ $\left.(2)_{0.4}\left(\mathrm{H}_{4} \mathrm{NMP}\right)_{2}\left(\mathrm{H}_{2} \mathrm{O}\right)_{4}\right]\left(\mathrm{HSO}_{4}\right)_{2} \cdot 4 \mathrm{H}_{2} \mathrm{O}$ were isolated for the lanthanide combinations $\mathrm{Eu}_{0.8} \mathrm{~Tb}_{0.2}$ and $\mathrm{Tb}_{0.8} \mathrm{Eu}_{0.2}$ using the same procedure described above. Anal. calcd for $\mathrm{Eu}_{1.6} \mathrm{~Tb}_{0.4} \mathrm{C}_{6} \mathrm{H}_{38} \mathrm{~N}_{2} \mathrm{O}_{34} \mathrm{P}_{6} \mathrm{~S}_{2}$ : C 5.82, H 3.09, N 2.26, S 5.17; found $\mathrm{C} 5.36, \mathrm{H} 3.01, \mathrm{~N} 2.18, \mathrm{~S} 4.80$. Anal. calcd for $\mathrm{Tb}_{1.6} \mathrm{Eu}_{0.4} \mathrm{C}_{6} \mathrm{H}_{38} \mathrm{~N}_{2} \mathrm{O}_{34} \mathrm{P}_{6} \mathrm{~S}_{2}$ : C 5.78, H 3.07, N 2.25, S 5.14; found C 5.43, H 2.99, N 2.36, S 5.10.

Structural Determinations. Single-crystal X-ray diffraction data for $\mathrm{Pr}^{3+}, \mathrm{Nd}^{3+}, \mathrm{Sm}^{3+}$, and $\mathrm{Tb}^{3+}$ derivatives of Series I were collected at room temperature with a Bruker D8 Venture using graphitemonochromated Mo $\mathrm{K} \alpha(\lambda=0.71073 \AA)$ radiation or a Rigaku AFC12 goniometer equipped with an enhanced sensitivity (HG) Saturn724+ detector mounted at the window of an RF-E+ Super Bright molybdenum rotate anode generator with HF Varimax optics ( $100 \mathrm{~m}$ focus, $\lambda=0.770 \AA$ ). The structures were solved by the direct methods, ${ }^{37}$ which revealed the position of all non-hydrogen atoms. These atoms were refined on $\mathrm{F}^{2}$ by a full-matrix least-squares procedure using anisotropic displacement parameters. ${ }^{38}$ Hydrogen atoms were placed at calculated positions and refined using a riding model, except for the water, $\mathrm{HSO}_{4}^{-}$anion, and phosphonic acid $\mathrm{O}-\mathrm{H}$ hydrogens, which were located from the Fourier difference density 
maps and refined using a riding model with $\mathrm{O}-\mathrm{H}$ distance restraints. The Olex $2^{39}$ or SHELXTL software was used as a graphical interface.

The crystal structures of the remaining compounds of Series I $\left(\mathrm{Ln}^{3+}=\mathrm{Eu}, \mathrm{Gd}, \mathrm{Er}\right.$, and $\left.\mathrm{Yb}\right)$ were determined from synchrotron X-ray powder diffraction data (SXRPD) or laboratory X-ray powder diffraction data (LXRPD) using the Rietveld method ${ }^{40}$ and the crystal structure of the $\mathrm{Tb}^{3+}$ derivative as the starting model. SXRPD were collected at the high-resolution BL04-MSPD beamline of ALBA, the Spanish Synchrotron Radiation Facility (Barcelona, Spain). A wavelength of $0.4124 \AA$ was selected with a double-crystal Si (111) monochromator and determined from a Si640d NIST standard $(a=$ $5.43123 \AA$ ) measurements, using an MYTHEM detector. The capillary was rotated during data collection to improve diffracting particle statistics, and patterns were collected over the angular range of $0.33-44.5^{\circ}(2 \theta)$. LXRPD for other compounds of both Series I and II were collected on a D8 ADVANCE (Bruker AXS) diffractometer equipped with a Johansson $\mathrm{Ge}(111)$ primary monochromator giving a monochromatic Mo radiation $(\lambda=0.7093$ $\AA$ ) and using the energy-dispersive linear detector LYNXEYE XE 500 $\mu \mathrm{m}$. Data were collected in the angular region of $2.5-45^{\circ}(2 \theta)$, with a step size of $0.01^{\circ}$ and a counting time of $\sim 1536 \mathrm{~s} / \mathrm{step}$. For compounds SD-Tb-I, Eu-I-230, and Tb-I-230, the crystal structures were obtained by Rietveld refinement using as a starting model the structure of $\left[\mathrm{La}_{2}\left(\mathrm{H}_{4} \mathrm{NMP}\right)_{2}\left(\mathrm{H}_{2} \mathrm{O}\right)_{3}\left(\mathrm{SO}_{4}\right)\right] \cdot 2 \mathrm{H}_{2} \mathrm{O}$ (CCDC\# 1496873). ${ }^{41}$ For compounds of Series II $\left(\mathrm{Ln}^{3+}=\mathrm{Pr}, \mathrm{Nd}, \mathrm{Eu}, \mathrm{Gd}\right.$, and $\mathrm{Tb}$ ), the crystal structure was solved for the $\mathrm{Tb}^{3+}$ derivative $(\mathrm{Tb}$ II) by the direct methods using the program EXPO2014. ${ }^{42}$ Partial structural models were obtained, and the missing atoms were localized by difference of Fourier maps. All crystal structures were optimized by the Rietveld method ${ }^{40}$ using the program GSAS $^{43}$ and the graphic interface EXPGUI. ${ }^{44}$ The following soft constraints were imposed in order to preserve chemically reasonable geometries for the phosphonate, amine, and sulfate groups. The soft constrains were $/ \mathrm{PO}_{3} \mathrm{C}$ tetrahedron $/ \mathrm{P}-\mathrm{O}(1.53(1) \AA), \mathrm{P}-\mathrm{C}(1.80(1) \AA ̊), \mathrm{O}-\mathrm{O}$ $(2.55(2) \AA), \mathrm{O}-\mathrm{C}(2.73(2) \AA) ; / \mathrm{N}\left(\mathrm{CH}_{2}\right)_{3}$ amine group $/ \mathrm{N}-\mathrm{C}$ $(1.50(1) \AA), \mathrm{C}-\mathrm{C}(2.45(2) \AA), \mathrm{N}-\mathrm{P}(2.68(2) \AA)$, and $/ \mathrm{SO}_{4}$ tetrahedron/S-O (1.46(1) $\AA$ ) and O-O (2.45(2) $\AA)$. No attempts to locate the $\mathrm{H}$ atoms were carried out due to the limited quality of the XRPD data. For the other compounds of this series, Pr-II and GdII, their structures were obtained by Rietveld refinement using the structure of $\mathbf{T b}$-II as the initial model.

Thermodiffractometric data for Tb-I, Er-I, and Tb-II were obtained for the samples loaded in an Anton Paar HTK1200N Camera, under static air, on a PANanalytical X'Pert Pro automated diffractometer. Data were collected in the Bragg-Brentano reflection configuration with $\mathrm{Cu} \mathrm{K} \alpha_{1}$ and the X'Celerator detector. Data were collected at different temperature intervals from room temperature to $250{ }^{\circ} \mathrm{C}$. A heating rate of $5{ }^{\circ} \mathrm{C} \cdot \mathrm{min}^{-1}$ and a delay time of $5 \mathrm{~min}$ to ensure thermal stabilization were used. XRPD patterns were recorded in the region of $4-70^{\circ}(2 \theta)$ with a step size of $0.017-0.033^{\circ}$ and an equivalent counting time of $\sim 57-100 \mathrm{~s} /$ step. A crystallographic study at $95 \%$ relative humidity $(\mathrm{RH})$ and different temperatures was also collected for Tb-I on a D8 ADVANCE (Bruker AXS) using an Anton Paar MHC-trans chamber. Data were collected between 30 and $80^{\circ} \mathrm{C}$ using a heating rate of $5{ }^{\circ} \mathrm{C} / \mathrm{min}$. The data range was between 3 and $20^{\circ}(2 \theta)$ with a step size of $0.02^{\circ}$ and an equivalent counting time of $\sim 384 \mathrm{~s} /$ step. Samples were held at each temperature for $10 \mathrm{~min}$ before recording any pattern, giving sufficient time for any transformation to take place.

Particle Size Determination. The particle size measurements were carried out using a Zetasizer Nano ZS from Malvern. Particle suspensions were prepared at a concentration of $9 \mathrm{mg} / \mathrm{mL}$ in isopropanol, and they were stirred and sonicated in a water bath for six sequential cycles of $10 \mathrm{~min}$ to obtain a homogeneous dispersion. The size was determined via dynamic light scattering (DLS) using a $632.8 \mathrm{~nm}$ wavelength laser as the light source. Then, the measurement was performed measuring backscattered light at $173^{\circ}$ in order to minimize multiple scattering, and the results were averaged and presented in intensity (raw data). The samples were measured in $1 \mathrm{~cm}$ path length disposable polystyrene cuvettes.
Photoluminescence (PL) Studies. Photoluminescence spectra of powders were carried out on a Carl Zeiss Axio Imager.A2m microscope in fluorescence mode using an HBO 100 mercury lamp. The PL signal was collected using an Ocean Optics QE Pro spectrometer connected to the microscope via a fiber optic waveguide.

Proton Conductivity Studies. Impedance measurements of the powdered polycrystalline compounds were carried out on cylindrical pellets ( $\sim 5 \mathrm{~mm}$ diameter; $\sim 0.9-1.1 \mathrm{~mm}$ thickness) obtained by pressing $\sim 30-40 \mathrm{mg}$ of sample at $250 \mathrm{MPa}$ for 1 min between porous $\mathrm{C}$ electrodes (Sigracet, GDL $10 \mathrm{BB}$, no $\mathrm{Pt}$ ). Sample cells were placed inside a temperature- and humidity-controlled chamber (Espec SH222), and impedance data were collected using an AUTOLAB PGSTAT302N or HP4284A impedance analyzer over the frequency range from 0.1 or $20 \mathrm{~Hz}$ to $1 \mathrm{MHz}$ with an applied voltage of 0.35 or $1 \mathrm{~V}$, respectively. Measurements were electronically controlled using the Nova or WinDETA package of programs. ${ }^{45}$ In order to equilibrate the water content, pellets were first preheated $\left(0.2^{\circ} \mathrm{C} / \mathrm{min}\right)$ from 25 to $80{ }^{\circ} \mathrm{C}$ at 75 and $95 \% \mathrm{RH}$. Impedance spectra were recorded on cooling using stabilization times of $5 \mathrm{~h}$ for each temperature $(80,70$, $60,50,40,30$, and $25^{\circ} \mathrm{C}$ ). Water condensation on the sample was avoided by reducing first the relative humidity before decreasing the temperature. The total pellet resistance $\left(R_{\mathrm{T}}\right)$ was obtained from the intercept of the spike and/or the arc (low-frequency end) on the $Z^{\prime}$ axis from the Nyquist plots. In addition, for the sulfate-deficient compounds (SD-Ln-I), samples were kept at $80{ }^{\circ} \mathrm{C}$ and $95 \% \mathrm{RH}$ for 80-90 h, washed with DI water, and dried in air.

Modeling Approaches. Ab Initio Electronic Structure Calculations. Plane wave DFT electronic structure calculations were performed for one unit cell of Tb-I using the Quantum Espresso package. ${ }^{46-48}$ The PBE functional and PAW pseudopotentials were used for all atoms with the exception of $\mathrm{Tb}$, where a PAW + GGA pseudopotential was used. The $4 \mathrm{f}$ electrons of $\mathrm{Tb}$ were treated as valence electrons. Calculations were done using a 170 Ry kinetic energy cutoff for the wave function and $680 \mathrm{Ry}$ for the kinetic energy cutoff for the charge density and potential. The convergence of energy with kinetic energy cutoff was investigated (Figure S1). A total of 450 bands were calculated. Only the Gamma point was used for all calculations. The valence charge density of the material was extracted, and using the chargemol code, the DDEC6 partial charges were calculated. ${ }^{49,50}$ Partial charge distribution for the material Tb-I can be found in Figure S2 and Table S1.

Diffusion Coefficient and Proton Conductivity. The first step in all calculations of proton conductivity is to compute the mean squared displacement, MSD, of the protons, as a function of simulation time, for an ensemble of $\mathrm{N}$ protons

$$
\operatorname{MSD}=\frac{1}{N} \sum_{i=1}^{N}\left|r^{i}(t)-r^{i}(0)\right|^{2}
$$

The diffusion coefficient $D$ of a particle type is connected to the mean squared displacement MSD, and especially for free diffusion, their relationship is linear as shown

$$
\text { MSD }=2 n D t
$$

In this case, it is possible to calculate the diffusion coefficient from eq 3

$$
D=\lim _{t \rightarrow \infty}\left[\frac{1}{6 t} \mathrm{MSD}\right]
$$

and the conductivity using the Nernst-Einstein equation

$$
\sigma=\frac{n Z^{2} D}{k_{\mathrm{B}} T}
$$

In this work, eq 3 will be used to extract the diffusion coefficient, and hence, the diffusion processes are treated as linear ones. In the simulations done in this work, the acidic hydrogens of the structure (hydrogen sulfate and phosphonic acidic hydrogens) were used as the source of diffusive protons. Calculation of the MSD for various temperatures resulted in calculations of $\sigma$ as a function of $T$. Inserting 
$\log [\sigma]$ and $1000 / T$ in an Arrhenius plot extracts the apparent activation energy for the proton conduction process (Figure S3).

Molecular Dynamics Simulations. The LAMMPS code was used for all classical MD simulations. ${ }^{51}$ A single unit cell was used for all simulations. The system was treated as an NVT ensemble, and a Nose-Hoover thermostat was used to control the temperature. Most of the bonding force field parameters were derived using ab initio techniques. The bonds and angles were treated as harmonic, and relative stretching and bending constants $k_{\text {stretch }}$ and $k_{\text {bending }}$ were calculated at the DFT/B3LYP/6-311G++ $(\mathrm{d}, \mathrm{p})$ level. The bond and angle terms of the $\mathrm{Tb}-\mathrm{O}$ bonds and $\mathrm{O}-\mathrm{Tb}-\mathrm{O}$ angles were taken from the Universal force field. ${ }^{52}$ The OPLS Lennard-Jones parameters ${ }^{53-55}$ were also used for all elements with two exceptions (Table S2). For terbium atoms, the UFF values were used, and for protons, the LJ parameters were optimized, so the $\mathrm{OH}$ bond length would be reproduced in the simulations. For the calculation of the force field parameters, initial structures of the fragments $\mathrm{HSO}_{4}{ }^{-}, \mathrm{H}_{2} \mathrm{O}$, and $\mathrm{H}_{4} \mathrm{NMP}^{2-}$ were drawn with Avogadro software and were optimized at the UFF level. ${ }^{56}$ The UFF geometries were further optimized at the DFT/B3LYP/6-311G++(2d,2p) level for all fragments using the Gaussian code, G03 version. ${ }^{57}$ After the DFT optimization, the Hessian matrix was calculated to find the second derivatives of the energy with respect to the geometry. Using the Seminario method implemented in the VFFDT $\operatorname{code}^{58}$ and the Hessian matrix of each fragment, the bonding and angle force field parameters were derived. In order to keep the modeled crystal structure as stable as possible, the bond lengths and equilibrium angles were constrained to the values of the original structure. The acidic protons of the structure (hydrogen sulfate and phosphonate acidic hydrogens) were treated as nonbonded particles in the molecular dynamics simulations. The partial charges that were assigned to all atoms in the simulations are the DDEC6 charges. A summary of the process used for the calculations of the bonding parameters is shown in Figure S4.

Using purely ab initio charges, it was found that protons practically did not diffuse. Hence, the conductivity was heavily underestimated. The reason for that was considered to be the strength of electrostatic forces or limitations associated with fixed charge or point particle simulations that do not include atomic charge polarization models. So, as a charge scaling approach, the dielectric constant was varied, and short runs were executed to find an optimum value, so protons diffused at lower temperatures, and this value was found to be $\varepsilon=2 \varepsilon_{o}$ (Figure S5). The short simulations, for the investigation of the best dielectric constant value, were run for $1 \mathrm{~ns}$ each, with a $0.1 \mathrm{fs}$ time step, at $50{ }^{\circ} \mathrm{C}$. The longer $5 \mathrm{~ns}$ runs were done using a time step of 0.5 fs. A global cutoff of $10.0 \AA$ was applied for both Lennard-Jones and close-range electrostatic interactions in all simulations. Long-range electrostatic interactions were treated using the Ewald summation scheme implemented in LAMMPS. The protons were grouped so that the MSD of the group could be calculated. To accelerate and observe diffusion of protons, high-temperature MD runs needed to be done. In order to extract the temperature dependence of the diffusion coefficient, the temperature was varied from run to run with simulations conducted at 35,100 , and $150{ }^{\circ} \mathrm{C}$. Modeling the system as an NVT ensemble constrained the structure to the crystallographic one, so no phase transitions were observed during the hightemperature simulations. Lower-temperature properties were extrapolated from the high-temperature data using the Arrhenius and the Nernst-Einstein equations.

From the MSD data, the conductivity was calculated using the following form of the Nernst-Einstein equation

$$
\sigma=\frac{N Z^{2}}{V k_{\mathrm{B}} T} \lim _{t \rightarrow \infty}\left[\frac{1}{6 t} \mathrm{MSD}\right]
$$

The low-temperature data were calculated using the Arrhenius form of the conductivity

$$
\sigma=\sigma_{\mathrm{o}} \mathrm{e}^{-\left(E_{\mathrm{a}} / k_{\mathrm{B}} t\right)}
$$

Using $Z=1$ as the charge of protons, $N=16$ as the number of acidic protons, $V$ as the volume of the unit cell, the proton conductivity values from the MSD and activation energy were derived (Tables S3S4).

Preparation of Composite Membranes and Characterization. Composite membranes, N/SD-Eu-I and N/Tb-II, containing $3 \%$ of each solid were prepared. As a representative example, the preparation process of the $\mathbf{N} / \mathbf{T b}$-II composite membrane is described in detail. $18 \mathrm{mg}$ of $\mathbf{T b}$-II was dispersed in 2-propanol $(3 \mathrm{~mL})$ via magnetic stirring (10 $\mathrm{min})$ and sonication $(10 \mathrm{~min})$, in six subsequent cycles. The suspension was slowly added to the $20 \mathrm{wt} \%$ Nafion solution $(3 \mathrm{~g})$ in a flask under magnetic stirring for $\sim 2 \mathrm{~h}$, giving rise a viscous homogeneous suspension. The membrane was prepared by casting using a blade (BYK Instruments) onto a polycarbonate plate that was allowed to air-dry for $48 \mathrm{~h}$. Finally, the obtained membrane (with a thickness of 35-40 $\mu \mathrm{m}$ ) was peeled off from the polycarbonate plate. The pristine Nafion membrane was also prepared using the same procedure. All membranes were characterized by XRPD, thermal analysis under $\mathrm{N}_{2}$, SEM (FEI, Helios Nanolab 650), and energy-dispersive X-ray spectrometry (X-Max Oxford). Water uptake of the composite membranes was determined by measuring the weight variation before and after hydration. The samples, three specimens for each membrane, were first dried under vacuum at 60 ${ }^{\circ} \mathrm{C}$ for $24 \mathrm{~h}$, and the weights were measured. Then, the samples were immersed in deionized water for $24 \mathrm{~h}$, wiped with tissue paper to remove any excess water on the film surface, and rapidly weighed. A stable wet weight was remained after $48 \mathrm{~h}$ in distillated water. The water uptake was calculated as a weight gain (wt \%) referred to the dried sample.

Membrane Electrode Assembly (MEA) Preparation. For both the anode and cathode, the catalyst layer ink consisted of $\mathrm{Pt} / \mathrm{C}(40 \%$ Pt on Vulcan XC-72, E-TEK) with a Pt load of $1 \mathrm{mg} \mathrm{Pt} \cdot \mathrm{cm}^{-2}, 30 \%$ Nafion (1100 EW), and 2:1 isopropanol/water mixture as the dispersion medium. After sonicating for $3 \mathrm{~h}$, the catalyst ink was sprayed onto a nonwoven carbon paper gas diffusion layer with a Microporous Layer (MPL) and 5\% PTFE-treated (SIGRACET 39 BC GDL) using an automatic spraying system EFD.

Electrochemical Characterization of MEAs and In Situ Through-Plane Proton Conductivity. An experimental $5 \mathrm{~cm}^{2}$ single cell (ElectroChem Inc.) was used as cell hardware for all the electrochemical measurements. Performance tests were carried out using a Scribner 850e multi range fuel cell test system using hydrogen and oxygen $\left(200 \mathrm{~mL} \cdot \mathrm{min}^{-1}\right)$. The experiments were conducted under atmospheric pressure at 70,80 , and $90{ }^{\circ} \mathrm{C}$ cell temperatures and at $100 \%$ relative humidity of the gases. Polarization and power density curves were acquired only after the cell reached stable conditions, i.e., potential remained constant over time at a fixed current. Throughplane proton conductivities of the membranes were determined on the MEAs at 70,80 , and $90{ }^{\circ} \mathrm{C}$ and $100 \% \mathrm{RH}$ by means of electrochemical impedance spectroscopy (EIS) using a potentiostat Autolab PGStat30 equipped with an FRA module. The cell was continuously supplied $\left(200 \mathrm{mLmin}^{-1}\right)$ with humidified hydrogen (SHE, anode) and nitrogen (cathode). The amplitude of the sinusoidal signal was $10 \mathrm{mV}$, and the frequency range was $100 \mathrm{kHz}$ to $10 \mathrm{~Hz}$. The spectra were recorded under a DC bias potential of $0.45 \mathrm{~V}$. The through-plane proton conductivities of the membranes $\sigma_{\mathrm{TP}}\left(\mathrm{S} \mathrm{cm}^{-1}\right)$ were obtained using the following equation: $\sigma_{\mathrm{TP}}=L / R S$, where $L$ is the membrane thickness $(\mathrm{cm})$ and $S$ is the active area of the MEA $\left(5 \mathrm{~cm}^{2}\right)$. Durability tests were performed at $80{ }^{\circ} \mathrm{C}$ and $100 \%$ relative humidity by maintaining the operating MEA at a constant voltage of $0.5 \mathrm{~V}$ for $28,000 \mathrm{~s}$. The supplied current density was recorded during the extent of the experiment.

\section{RESULTS AND DISCUSSION}

The two polymorph series $\left[\operatorname{Ln}_{2}\left(\mathrm{H}_{4} \mathrm{NMP}\right)_{2}\left(\mathrm{H}_{2} \mathrm{O}\right)_{4}\right]\left(\mathrm{HSO}_{4}\right)_{2}$. $n \mathrm{H}_{2} \mathrm{O}\left(\mathrm{Ln}=\mathrm{Pr}^{3+}, \mathrm{Nd}^{3+}, \mathrm{Sm}^{3+}, \mathrm{Eu}^{3+}, \mathrm{Gd}^{3+}, \mathrm{Tb}^{3+}, \mathrm{Er}^{3+}\right.$, and $\mathrm{Yb}^{3+}$ and $n=4-5$; Series I) and $\left[\mathrm{Ln}\left(\mathrm{H}_{5} \mathrm{NMP}\right)\right] \mathrm{SO}_{4} \cdot 2 \mathrm{H}_{2} \mathrm{O}(\mathrm{Ln}=$ $\mathrm{Pr}^{3+}, \mathrm{Nd}^{3+}, \mathrm{Eu}^{3+}, \mathrm{Gd}^{3+}$, and $\mathrm{Tb}^{3+}$; Series II) were isolated by slow crystallization at $25{ }^{\circ} \mathrm{C}$. Polymorphs of Series I were 
Table 1. Crystallographic Data for Some Representative Members of Series I and II

\begin{tabular}{|c|c|c|c|c|c|}
\hline phase & Tb-I & $\operatorname{Pr}-I^{*}$ & SD-Tb-I & Tb-I-230 & Tb-II \\
\hline space group & $P 2_{1} / c$ & $P 2_{1} / c$ & $P 2_{1} / c$ & $P 2_{1} / c$ & $P-1$ \\
\hline chemical formula & $\mathrm{C}_{6} \mathrm{H}_{38} \mathrm{~N}_{2} \mathrm{O}_{34} \mathrm{P}_{6} \mathrm{~S}_{2} \mathrm{~Tb}_{2}$ & $\mathrm{C}_{6} \mathrm{H}_{38} \mathrm{~N}_{2} \mathrm{O}_{34} \mathrm{P}_{6} \mathrm{~S}_{2} \mathrm{Pr}_{2}$ & $\mathrm{C}_{6} \mathrm{H}_{34} \mathrm{~N}_{2} \mathrm{O}_{29} \mathrm{P}_{6} \mathrm{STb}_{2}$ & $\mathrm{C}_{6} \mathrm{H}_{22} \mathrm{~N}_{2} \mathrm{O}_{26} \mathrm{P}_{6} \mathrm{~S}_{2} \mathrm{~Tb}_{2}$ & $\mathrm{C}_{3} \mathrm{H}_{15} \mathrm{NO}_{15} \mathrm{P}_{3} \mathrm{STb}$ \\
\hline formula mass $\left(\mathrm{g} \cdot \mathrm{mol}^{-1}\right)$ & 1250.18 & 1214.14 & 1134.09 & 1106.06 & 589.06 \\
\hline$\lambda(\AA)$ & 0.71073 & 0.71073 & 0.4132 & 0.7093 & 0.7093 \\
\hline$a(\AA)$ & $8.4314(2)$ & $8.6510(4)$ & $8.5720(2)$ & $8.8138(3)$ & $10.0792(5)$ \\
\hline$b(\AA)$ & $19.2357(5)$ & $19.5394(9)$ & $16.2769(5)$ & $16.0812(7)$ & $9.5779(4)$ \\
\hline$c(\AA)$ & $10.5627(3)$ & $10.7660(5)$ & $10.5651(2)$ & $10.3891(3)$ & $9.3920(4)$ \\
\hline$\alpha\left(^{\circ}\right)$ & 90.0 & & 90.0 & 90.0 & $110.696(3)$ \\
\hline$\beta\left(^{\circ}\right)$ & $109.373(3)$ & $109.922(2)$ & $109.6499(11)$ & $109.9755(19)$ & $111.583(3)$ \\
\hline$\gamma\left({ }^{\circ}\right)$ & 90.0 & & 90.0 & 90.0 & $101.511(4)$ \\
\hline$V\left(\AA^{3}\right)$ & $1616.10(8)$ & $1710.93(14)$ & $1388.26(7)$ & $1383.92(11)$ & $729.91(6)$ \\
\hline$Z$ & 2 & 2 & 2 & 2 & 2 \\
\hline temperature $(\mathrm{K})$ & $150.0(2)$ & 100 & 298 & 298 & 298 \\
\hline range data $\left(^{\circ}\right)$ & $2.71-30.62$ & $2.09-27.55$ & $2.00-42.49$ & $4.20-47.98$ & $4.18-48.00$ \\
\hline independent reflections & 3244 & 3943 & 7847 & 2183 & 2297 \\
\hline data/restrains/ parameters & $3715 / 0 / 237$ & $3943 / 52 / 321$ & $6814 / 68 / 131$ & $4428 / 51 / 122$ & $4430 / 50 / 121$ \\
\hline$R_{\mathrm{WP}}$ & & & 0.0682 & 0.0921 & 0.1109 \\
\hline$R_{\mathrm{P}}$ & & & 0.0479 & 0.0684 & 0.0835 \\
\hline$R_{\mathrm{F}}$ & & & 0.0188 & 0.0250 & 0.0393 \\
\hline$R$ factor $[I>2 \sigma(I)]$ & $R_{1}=0.0302^{a} ; w R_{2}=0.0572^{b}$ & $R_{1}=0.0334^{a} ; w R_{2}=0.0994^{b}$ & & & \\
\hline$R$ factor (all data) & $R_{1}=0.0386^{a} ; w R_{2}=0.0597^{b}$ & $R_{1}=0.0373^{a} ; w R_{2}=0.1018^{b}$ & & & \\
\hline GoF & 1.035 & 1.096 & & & \\
\hline $\mathrm{CCDC}$ number $^{c}$ & 1980608 & 2003911 & 1980609 & 1980604 & 1980607 \\
\hline
\end{tabular}

${ }^{a} R_{1}(F)=\Sigma\left\|F_{\mathrm{o}}|-| F_{\mathrm{c}}\right\| / \Sigma\left|F_{\mathrm{o}}\right|{ }^{b} w R_{2}\left(F^{2}\right)=\left[\Sigma w\left(F_{\mathrm{o}}{ }^{2}-F_{\mathrm{c}}{ }^{2}\right)^{2} / \Sigma F^{4}\right]^{1 / 2} \cdot{ }^{c} \mathrm{CCDC}$ contains the supplementary crystallographic data for this work.

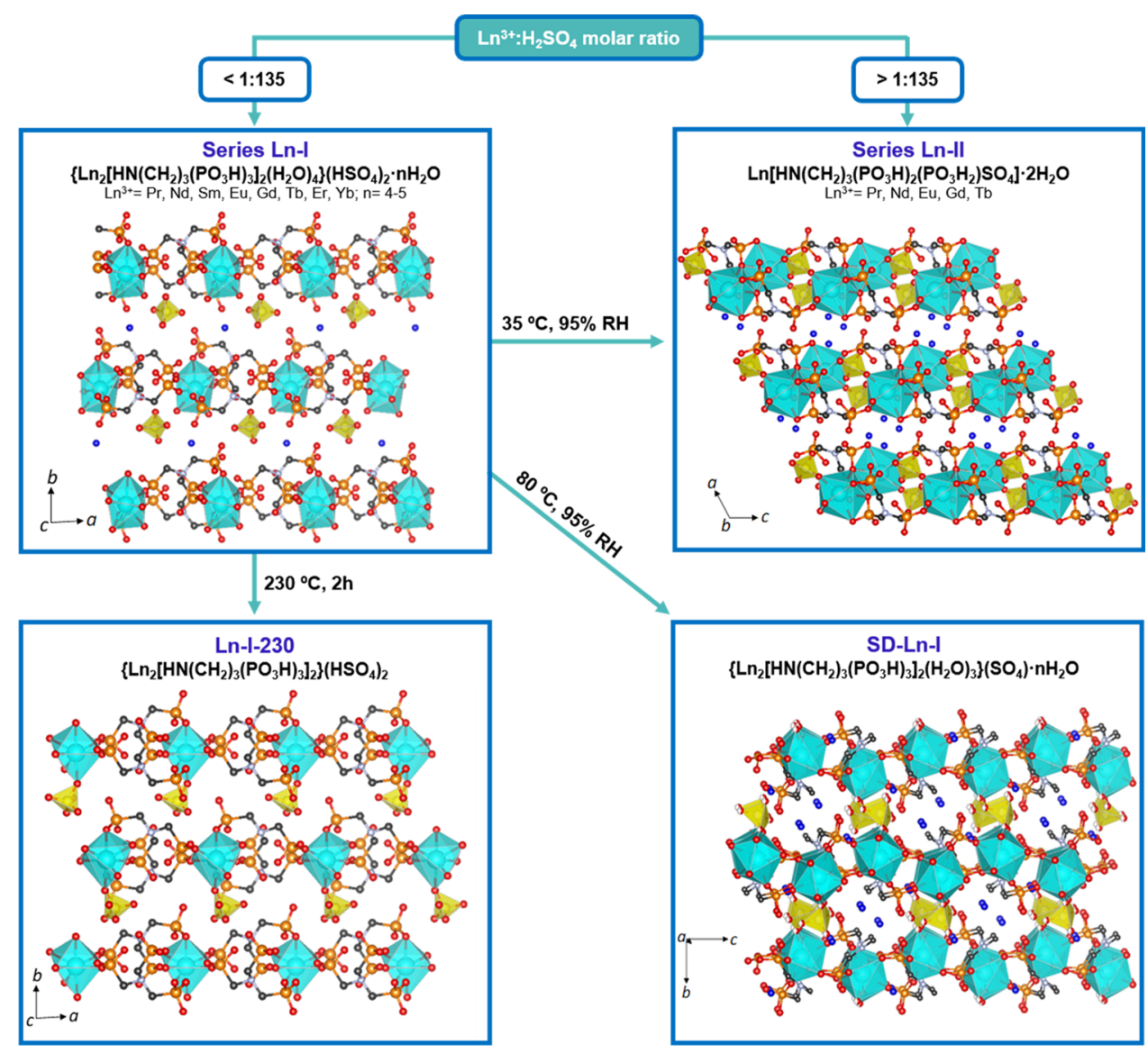

Figure 1. Phase transformations of $\mathrm{Ln}^{3+}$-nitrilotris(methylenephosphonates). Yellow tetrahedra represent hydrogen sulfate/sulfate groups, blue polyhedra represent $\mathrm{LnO}_{n}$, and lattice water molecules are shown as blue spheres. 
obtained by varying the molar ratio $\mathrm{Ln}^{3+} / \mathrm{H}_{6} \mathrm{NMP} / \mathrm{H}_{2} \mathrm{SO}_{4} /$ $\mathrm{H}_{2} \mathrm{O}$ from 1:5:19.3:3715 up to $1: 5: 135: 3715$, while those of Series II required addition of higher $\mathrm{H}_{2} \mathrm{SO}_{4}$ (95\%) amounts up to a ratio 1:5:193:3715. Appropriate ratio adjustments were made depending on the lanthanide ion. These synthetic strategies resulted in the formation of mixed-ligand complexes in solution as precursors to the crystalline product phases. In addition, for Series I, bimetallic solid solutions can be prepared within a wide range of compositions, i.e., $\mathrm{Eu}_{0.8} \mathrm{~Tb}_{0.2}$ and $\mathrm{Tb}_{0.8} \mathrm{Eu}_{0.2}$. Photoluminescence properties of $\mathbf{T b} \mathbf{b} \mathbf{I}, \mathbf{S m}-\mathbf{I}$, and bimetallic solids were measured (Figures S6 and S7). In all cases, the emission that is recorded for the lanthanide ion containing samples arises from direct excitation of the lanthanide ion. The $\mathrm{H}_{6} \mathrm{NMP}$ and $\mathrm{SO}_{4}{ }^{2-}$ ligands play no detectable role in the emission of light. ${ }^{33}$ However, in the spectrum of $\mathbf{E u}_{\mathbf{0 . 8}} \mathbf{T b}_{\mathbf{0 . 2}}-\mathrm{I}$, the most intense peak corresponds to the $\mathrm{Tb}^{3+5} \mathrm{D}_{4} \rightarrow{ }^{7} \mathrm{~F}_{5}$ transition, which demonstrates the greater relative intensity of the emission from $\mathrm{Tb}^{3+}$ than from $\mathrm{Eu}^{3+}$ (Figure S7), whatever the molar percentage of both lanthanide ions was. This was evidenced further in the overlapping peak around $620 \mathrm{~nm}\left(\mathrm{Eu}^{3+5} \mathrm{D}_{0} \rightarrow{ }^{7} \mathrm{~F}_{2}\right.$ and $\mathrm{Tb}^{3+5} \mathrm{D}_{4} \rightarrow{ }^{7} \mathrm{~F}_{3}$ transitions), where the compositional change to much greater $\mathrm{Eu}^{3+}$ content does not have an appreciable effect upon the relative intensity of the aggregated peak with respect to the peak at $542 \mathrm{~nm}\left(\mathrm{~Tb}^{3+}{ }^{5} \mathrm{D}_{4} \rightarrow{ }^{7} \mathrm{~F}_{5}\right.$ transition $)$. There is, however, a more pronounced splitting of the composite peak, which differentiates the $\mathrm{Eu}^{3+}$ and $\mathrm{Tb}^{3+}$ contributions, which arises from the increased contribution of the $\mathrm{Eu}^{3+}$ emission to this line.

Structural and Stability Features of Series I and II. The crystal structures of Series I compounds were solved by single-crystal X-ray diffraction or Rietveld analysis (Figure S8) for the other members of the series. These solids crystallize in the monoclinic system, with space group $P 2_{1} / c$, with all atoms situated in general positions (Table 1 and Table S1). The basic layered crystal structure, illustrated for the $\mathrm{Tb}^{3+}$ derivative, resembles that found for $\left[\mathrm{Ln}\left(\mathrm{H}_{4} \mathrm{NMP}\right)\left(\mathrm{H}_{2} \mathrm{O}\right)_{2}\right](\mathrm{Cl}) \cdot 2 \mathrm{H}_{2} \mathrm{O},{ }^{33}$ in which the metal ion is surrounded by two coordinated water molecules and six oxygen atoms from four different $\mathrm{H}_{4} \mathrm{NMP}^{2-}$ ligands. Each zwitterionic $\mathrm{H}_{4} \mathrm{NMP}^{2-}$ ligand links four $\mathrm{Ln}^{3+}$ ions. Two $\mathrm{H}_{4} \mathrm{NMP}^{2-}$ ligands are bidentate, forming eightmembered rings, and the remaining two are monodentate, resulting in isolated $\mathrm{LnO}_{8}$ polyhedra (Figure S9).

Single-crystal data indicate that sulfate is present in the structure as a $\mathrm{HSO}_{4}{ }^{-}$ion, as three $\mathrm{S}-\mathrm{O}$ bond lengths are found between $1.466(3)$ and 1.451(3) $\AA$, whereas the fourth one is much longer at $1.537(3) \AA$, as observed in the structure of $\mathrm{Tb}\left(\mathrm{SO}_{4}\right)\left(\mathrm{HSO}_{4}\right) .{ }^{59}$ Moreover, crystallographic sites are fully occupied, which rules out the presence of $\mathrm{SO}_{4}{ }^{2-}$ ions. The noncoordinated $\mathrm{HSO}_{4}{ }^{-}$ions, together with lattice water molecules, are located between the cationic inorganic-organic layers (Figure 1). Importantly, the $\mathrm{HSO}_{4}^{-}$anions form hydrogen bonds through all four oxygen atoms with the coordinated waters (Ow1 and Ow2), lattice waters (Ow3 and $\mathrm{Ow} 4)$, the protonated phosphonate oxygens $(-\mathrm{P}-\mathrm{O}-\mathrm{H}, \mathrm{O} 2$, $\mathrm{O} 5$, and $\mathrm{O} 8)$, and with the deprotonated phosphonate groups (O3, O6, and O9). These interactions create extended unidirectional H-bonds along the $a$-axis (Figure S10, Table S6).

A structural deviation in Series I was found for the $\mathrm{Pr}^{3+}$ derivative upon slightly modifying the amount of $\mathrm{H}_{2} \mathrm{SO}_{4}$ (95\%) added to obtain a $\operatorname{Pr}^{3+} / \mathrm{H}_{6} \mathrm{NMP} / \mathrm{H}_{2} \mathrm{SO}_{4} / \mathrm{H}_{2} \mathrm{O}$ molar ratio of 1:5:95:3000. These synthesis conditions are the same as those used by Mendes and Almeida $\mathrm{Paz}^{41}$ albeit without a microwave treatment. The crystal structure of this compound, $\left\{\mathrm{Pr}_{2}\left[\left(\mathrm{H}_{4} \mathrm{NMP}\right)_{2}\left(\mathrm{H}_{2} \mathrm{O}\right)_{4}\right]\left(\mathrm{HSO}_{4}\right)_{2} \cdot 4 \mathrm{H}_{2} \mathrm{O}\right\}$, designated as Pr$\mathrm{I}^{*}$, was solved from single-crystal data and reveals the existence of two sulfate groups, each one having a half-site occupancy. Its structure features a $\mathrm{PrO}_{8}$ coordination environment in which one of the two coordinated water molecules is now halfsubstituted by a monodentate $\mathrm{HSO}_{4}{ }^{-}$ion, coordinated through $\mathrm{O} 11 \mathrm{~B}$ (Figure $\mathrm{S} 1 \mathrm{la}$ ). The remaining uncoordinated $\mathrm{HSO}_{4}^{-}$ ion is located, together with two lattice water molecules, in the interlayer region. As for the structure of the other Series I compounds, the layers are built up from $\mathrm{PrO}_{8}$ polyhedra interconnected via the phosphonate moieties. The sulfate ions interact with both coordinated and lattice water molecules and the oxygen atoms from the phosphonate groups, forming extended unidirectional hydrogen bonds (Figure $\mathrm{S} 11 \mathrm{~b}$ and Table S7). Compounds $\left[\mathrm{La}_{2}\left(\mathrm{H}_{4} \mathrm{NMP}\right)_{2}\left(\mathrm{H}_{2} \mathrm{O}\right)_{3}\left(\mathrm{SO}_{4}\right)\right] \cdot n \mathrm{H}_{2} \mathrm{O}$ $(n=2-8)$ previously reported ${ }^{41}$ can be envisioned as structural analogues of Series I compounds because they present similar layered features ( $a$ and $c$ parameters) but with variable interlayer distances ( $b$ axis) in order to accommodate different contents and arrangements of lattice water and $\mathrm{SO}_{4}{ }^{2-}$ ions.

The crystal structures of compounds of Series II, with general formula $\left.\left[\mathrm{Ln}\left(\mathrm{H}_{5} \mathrm{NMP}\right)\right]\left(\mathrm{SO}_{4}\right)\right] \cdot 2 \mathrm{H}_{2} \mathrm{O}\left(\mathrm{Ln}^{3+}=\mathrm{Pr}, \mathrm{Nd}\right.$, $\mathrm{Eu}, \mathrm{Gd}, \mathrm{Tb})$, were solved by $\mathrm{X}$-ray powder diffraction data (Figure S12). These solids crystallize in a triclinic unit cell (Table 1 and Table S5) with all atoms located in general positions. Their structures consist of chains of dimeric $\mathrm{Ln}_{2} \mathrm{O}_{14}$ polyhedra connected by bridging sulfate ions running along the $c$-axis (Figures 1 and 2). These chains are linked together

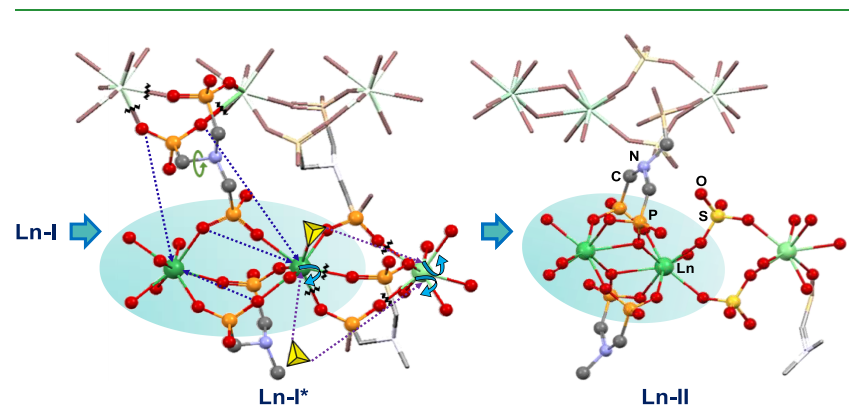

Figure 2. Tentative mechanism of dimer formation upon Ln-I to LnII transformation. Yellow tetrahedra represent hydrogen sulfate/ sulfate groups, and bent arrows represent leaving coordinated water.

through the phosphonate groups in the $b c$-plane (Figure S13). The $\mathrm{Ln}_{2} \mathrm{O}_{14}$ dimers, containing eight-coordinated lanthanide centers, are formed by bridging via $\mathrm{O} 1$ and $\mathrm{O} 2$ belonging to one phosphonate (P1). In addition, another phosphonate (P2) acts simultaneously as a chelate (O4 and $\mathrm{O} 6)$ for each $\mathrm{Ln}^{3+}$ ion while bridging (via O6) the two $\mathrm{Ln}^{3+}$ ions of the dimer. The third phosphonate (P3) binds exclusively in a monodentate fashion to the $\mathrm{Ln}^{3+}$ ions (Figure S13). Furthermore, the structure contains two lattice water molecules situated and forming $\mathrm{H}$-bonding interactions between the layers (Figure S10). Extended bidimensional ( $b c$ plane) H-bonding networks (Table S8) result from linkages mainly between lattice water (Ow1 and Ow2), the phosphonate oxygen atoms (O7 and $\mathrm{O} 4)$, and the sulfate oxygen atom (Os2). This conduction pathway, therefore, contrasts with that found for the compounds of Series I, which is preferentially unidirectional. 
The stability of both families of compounds was studied by thermal analysis and thermodiffraction. Solids of Series I progressively lose water upon heating, accompanied by structural changes before decomposition over $300{ }^{\circ} \mathrm{C}$ (Figure S14). The thermodiffraction patterns indicate that the solids exhibit a phase transformation at $\sim 100-120{ }^{\circ} \mathrm{C}$ before complete dehydration, accompanied by a significant weight loss, as detected in the TG curves. The crystalline phase that remains at $230{ }^{\circ} \mathrm{C}$ is consistent with an anhydrous structure (i.e., for Tb-I, the observed weight loss accounts for 8 water molecules per formula $11.8 \%$, calculated $11.5 \%$ ). The heavier $\mathrm{Ln}^{3+}$ derivatives, with a slightly higher water content, follow a similar behavior, except that the appearance of partially dehydrated intermediate phases starts at markedly lower temperatures $\left(60{ }^{\circ} \mathrm{C}\right.$ for $\left.\mathrm{Er}^{3+}\right)$ before full dehydration (observed weight loss for 9 water molecules 14.3\%, calculated $12.6 \%)$. Thus, a different weight loss profile is observed in the corresponding TG curves (Figure S14). The compounds remain stable up to $250-270{ }^{\circ} \mathrm{C}$ before ligand decomposition occurs.

The anhydrous compounds of Series I crystallize in a monoclinic cell (Table 1 and Table S5 and Figure S15) with parameters similar to those of the precursor phase, preserving the same connectivity between the ligand phosphonate groups and the seven-coordinated $\mathrm{Ln}^{3+}$ ions within the layer (Figure S16). The $\mathrm{Ln}^{3+}$ coordination environment contains one oxygen atom originating from the sulfate group instead of two coordinated water molecules, as noticed for the Series I compounds. The sulfate group also interacts through hydrogen bonding with oxygen atoms (O1, O3, and O6) from the phosphonate groups from the adjacent layer (Table S9).

Compounds of Series I experience an irreversible solid-state transformation to phase II at $35{ }^{\circ} \mathrm{C}$ and $95 \% \mathrm{RH}$ (Figure 1) as confirmed by powder diffraction. This transformation implies the transfer of a proton from a $\mathrm{HSO}_{4}{ }^{-}$group to one of the phosphonate ligands. The process is thought to be watermediated because this transformation is not observed upon dry heating of the solid up to $230{ }^{\circ} \mathrm{C}$ (Figure S14). As a result, the metal-ligand connectivity changes from $1: 4$ to $1: 3$, while the sulfate group substitutes the coordinated water molecules and bridges the newly formed $\mathrm{Ln}_{2} \mathrm{O}_{14}$ dimers (Figure 2). The isolated compound $\mathrm{Pr}-\mathrm{I}^{*}$, with the $\mathrm{HSO}_{4}{ }^{-}$ions coordinated in a monodentate fashion to the lanthanide ion, can be considered as an intermediate stage during this transformation.

On the other hand, samples of Ln-I solids, which were studied by impedance spectroscopy, i.e., were heated at $80{ }^{\circ} \mathrm{C}$ and $95 \% \mathrm{RH}$, converted into a phase formulated as $\left[\mathrm{Ln}_{2}\left(\mathrm{H}_{4} \mathrm{NMP}\right)_{2}\left(\mathrm{H}_{2} \mathrm{O}\right)_{3}\right]\left(\mathrm{SO}_{4}\right) \cdot n \mathrm{H}_{2} \mathrm{O},(\mathrm{Ln}=\mathrm{Pr}, \mathrm{Nd}, \mathrm{Eu}, \mathrm{Gd}$, $\mathrm{Tb}$ and $n=4-5$ ); hereinafter SD-Ln-I (Figure 1). According to elemental analyses and PXRD patterns (Figure S17), the latter composition matches with that reported for the $\mathrm{La}^{3+}$ derivative $\left[\mathrm{La}_{2}\left(\mathrm{H}_{4} \mathrm{NMP}\right)_{2}\left(\mathrm{SO}_{4}\right)\right] \cdot n \mathrm{H}_{2} \mathrm{O}(n=2-11){ }^{41}$ This transformation results from partial dissolution of the initial compounds, as revealed by the presence of dissolved $\mathrm{Ln}^{3+}$ and phosphonate upon soaking the samples in water, which gives rise to solids having a sulfate content reduced by half. Solids SD-Ln-I remain stable for, at least, 4 days at $80{ }^{\circ} \mathrm{C}$ and $95 \%$ $\mathrm{RH}$, as demonstrated by XRPD and thermal analysis. Interestingly, loss of sulfate was complete for the $\mathrm{Yb}^{3+}$ derivative. A similar behavior was previously observed for the isoreticular compounds $\left[\mathrm{Ln}\left(\mathrm{H}_{4} \mathrm{NMP}\right)\left(\mathrm{H}_{2} \mathrm{O}\right)_{2}\right](\mathrm{Cl}) \cdot 2 \mathrm{H}_{2} \mathrm{O} .^{33,35}$

The crystal structure of the sulfate-deficient derivative, SDLn-I, has been reported elsewhere, ${ }^{41}$ and here, we report the crystallographic data for $\mathrm{Tb}^{3+}$ derivative (SD-Tb-I), from Rietveld refinement (Table 1, Figure S18). For SD-Ln-I compounds containing other $\mathrm{Ln}^{3+}$ ions, the limited quality of their XRPD patterns prevented further structural refinement. Formation of SD-Tb-I does not imply a change in charge and connectivity of the ligand, but simply a substitution of two uncoordinated $\mathrm{HSO}_{4}^{-}$ions and one coordinated water molecules by one $\mathrm{SO}_{4}{ }^{2-}$ ion coordinated in a monodentate fashion, through $\mathrm{O} 10$ (Figure 1). The $\mathrm{SO}_{4}{ }^{2-}$ ion points toward the interlayer region interacting via $\mathrm{H}$-bonds with the noncoordinated oxygen atoms $\mathrm{O} 3$ and $\mathrm{O} 6$ from the phosphonate groups as well as with the coordinated water Ow1 and the lattice water Ow3 (Table S10). An extended Hbonding network is thus created along the $a$-axis, through interconnected lattice water Ow2 (Figure S10), which differs from that in Series I compounds.

In contrast to Series I compounds, those of Series II exhibit a unique low-temperature weight loss corresponding to removal of lattice waters, i.e., for Tb-II, observed $7.0 \%$, calculated 6.0\%, (Figure S19a). According to the thermodiffraction patterns (Figure S19b), solids remain crystalline up to $140{ }^{\circ} \mathrm{C}$. Compounds progressively lose crystallinity above 140 ${ }^{\circ} \mathrm{C}$ until their ultimate thermal decomposition at $\sim 250{ }^{\circ} \mathrm{C}$. The dehydration of these solids led to highly hygroscopic materials at high relative humidity values. The solids of this series remain stable in composition at high relative humidity (95\%) and $80{ }^{\circ} \mathrm{C}$ (Figure S20).

Proton Conductivity. The notion of incorporating anions to balance the cationic lanthanide- $\mathrm{H}_{x} \mathrm{NMP}$ layers ${ }^{3,35}$ opens possibilities for design of novel structures, but now containing proton conductivity-enhancing anions through the formation of extended H-bonding networks. Hence, the incorporation of sulfate ions serves this purpose and gives the opportunity to evaluate how these could influence proton conductivity.

Due to the instability of compounds of Series I in high humidity conditions, electrochemical impedance spectroscopy (EIS) measurements were conducted on SD-Ln-I and $230^{\circ} \mathrm{C}$ heated samples. Nevertheless, in an effort to understand the process of proton conduction in $\left[\mathrm{Ln}_{2}\left(\mathrm{H}_{4} \mathrm{NMP}\right)_{2}\left(\mathrm{H}_{2} \mathrm{O}\right)_{4}\right]$ $\left(\mathrm{HSO}_{4}\right)_{2} \cdot n \mathrm{H}_{2} \mathrm{O}$, ab initio electronic structure calculations and classical molecular dynamics simulations were performed for Tb-I. Molecular dynamics (MD) simulations ${ }^{51}$ show that the proton conduction mechanism is Grotthuss-type (calculated activation energy $0.35 \mathrm{eV}$ ). The MD trajectories of the protons (Figure 3) show that lattice water molecules act as strong proton carriers since a large protonic density can be visualized

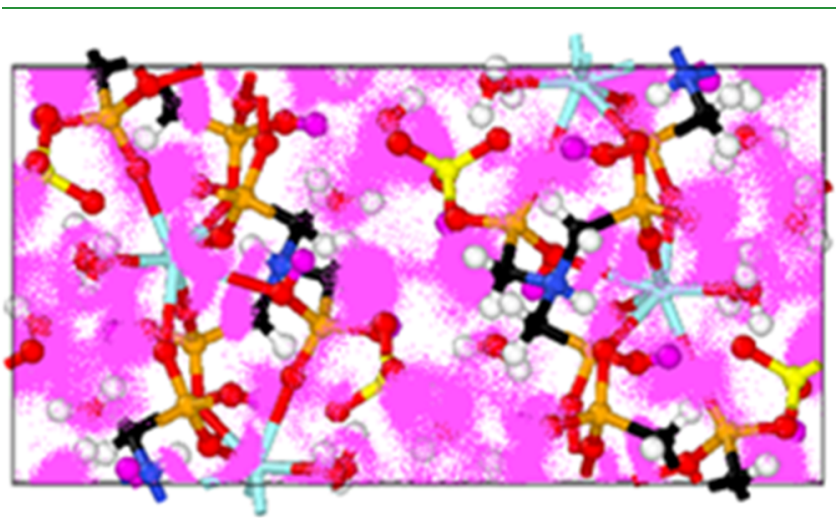

Figure 3. Proton trajectories occurring in a single unit cell. 
around them. Coordinated phosphonate oxygens, as well as noncoordinated oxygens, also contribute. Nevertheless, from single-crystal X-ray diffraction data, there seem to be specific $\mathrm{H}$-bonding pathways along the $a$-axis (Figure S10). The estimated proton conductivity values calculated from $\mathrm{MD}$ simulations range between $1.4 \times 10^{-3} \mathrm{~S} \cdot \mathrm{cm}^{-1}$, at $35{ }^{\circ} \mathrm{C}$, and $6.8 \times 10^{-3} \mathrm{~S} \cdot \mathrm{cm}^{-1}$ at $80{ }^{\circ} \mathrm{C}$.

The proton conductivities obtained for Ln-I derivatives, from the Nyquist plots (Figures S21 and S22), are given in Table 2. All these compounds display high proton con-

Table 2. Proton Conductivity and Activation Energy Values for the Compounds of Series I and II

\begin{tabular}{lccccc} 
& \multicolumn{2}{c}{$95 \% \mathrm{RH}$} & & \multicolumn{2}{c}{$75 \% \mathrm{RH}$} \\
\cline { 2 - 3 } \cline { 5 - 6 } sample & $\sigma\left(\mathrm{S} \cdot \mathrm{cm}^{-1}\right)$ & $E_{\mathrm{a}}(\mathrm{eV})$ & & $\sigma\left(\mathrm{S} \cdot \mathrm{cm}^{-1}\right)$ & $E_{\mathrm{a}}(\mathrm{eV})$ \\
$\mathrm{SD}-\mathrm{Tb}-\mathrm{I}$ & $1.5 \times 10^{-2}$ & 0.31 & & $2.2 \times 10^{-3}$ & 0.18 \\
Eu-I-230 & $3.6 \times 10^{-2}$ & 0.11 & & $1.1 \times 10^{-2}$ & 0.14 \\
Tb-I-230 & $2.9 \times 10^{-2}$ & 0.14 & & $1.1 \times 10^{-2}$ & 0.17 \\
$\mathrm{Yb}-\mathrm{I}-230$ & $2.8 \times 10^{-3}$ & 0.17 & & $1.9 \times 10^{-4}$ & 0.26 \\
Pr-II & $3.5 \times 10^{-3}$ & 0.26 & & $6.0 \times 10^{-4}$ & 0.22 \\
Tb-II & $1.1 \times 10^{-3}$ & 0.33 & & $5.7 \times 10^{-5}$ & 0.29 \\
\hline
\end{tabular}

ductivities, ranging from $\sim 2.8 \times 10^{-3}\left(\mathrm{Yb}^{3+}\right)$ to $\sim 3.6 \times 10^{-2} \mathrm{~S}$. $\mathrm{cm}^{-1}\left(\mathrm{Eu}^{3+}\right)$ at $80{ }^{\circ} \mathrm{C}$ and $95 \% \mathrm{RH}$, and activation energy values $(0.11-0.31 \mathrm{eV})$ typical of a Grotthuss-type mechanism of proton transfer (Figure 4). Post-impedance analysis revealed

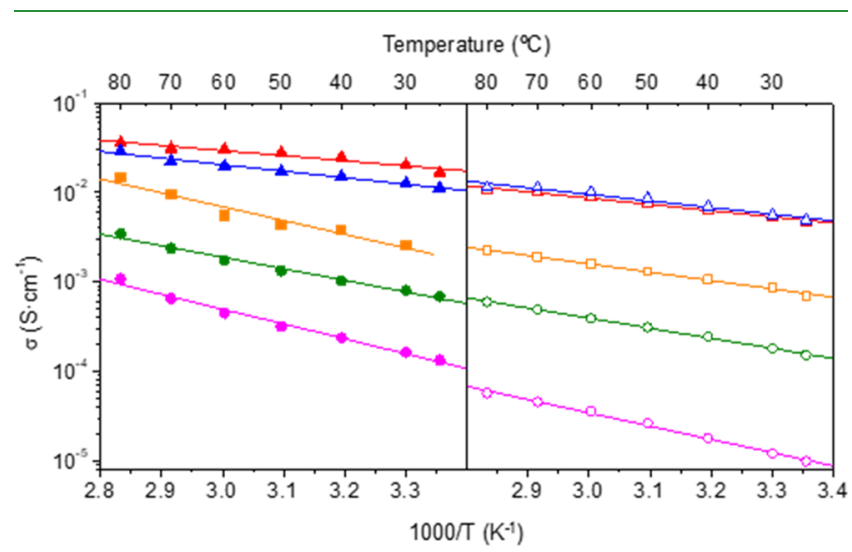

Figure 4. Arrhenius plots at 95\% (closed symbols) and $75 \% \mathrm{RH}$ (open symbols) for selected compounds of Series I and II: SD-Tb-I (yellow square), Eu-I-230 (red triangle), Tb-I-230 (blue triangle), Pr-II (green circle), and Tb-II (pink circle). that samples heated at $230{ }^{\circ} \mathrm{C}$ also show high water content, with weight loss between $8.2\left(\mathrm{~Tb}^{3+}\right)$ and $13.9 \%\left(\mathrm{Yb}^{3+}\right)$, up to $230{ }^{\circ} \mathrm{C}$ (Figure S23), as well as a tendency to evolve to sulfatedeficient materials according to the elemental analysis. However, their XRD patterns only show the presence of the initial $230{ }^{\circ} \mathrm{C}$-heated phase with lower crystallinity, which would indicate that the adsorbed water is external to the crystalline phase.

The proton conductivities of these materials decay at lower $\mathrm{RH}$, a feature common in water-mediated proton conductors. ${ }^{60}$ In addition, these proton conductivity values are considerably higher than those of the analogous chloridecontaining compounds $\left[\mathrm{Ln}\left(\mathrm{H}_{2} \mathrm{NMP}\right)\left(\mathrm{H}_{2} \mathrm{O}\right)_{2}\right](\mathrm{Cl}) \cdot 2 \mathrm{H}_{2} \mathrm{O},{ }^{33}$ indicating a prominent role of the sulfate ion in promoting efficient proton transfer. This enhancement of proton conductivity may be attributed to the high propensity of sulfate to establish H-bonding interactions with available species, such as water molecules and phosphonate groups. In addition, the obtained values are compared with those observed for Nafion 117 membranes $^{61,62}$ and are among the highest values reported for phosphonate-based lanthanide CPs. ${ }^{16,30,60,63-65}$

Compounds of Series II exhibit systematically lower proton conductivity values than those of Series I, approximately 1 order of magnitude (Table 2). This is even more evident at lower relative humidity $(75 \%)$. However, the proton conduction mechanism remains unchanged, as revealed by their low activation energy values. This behavior can be ascribed to the higher availability of sulfate oxygens present in compounds of Series I for establishing H-bonding networks, as shown by MD simulations. In light of this, it is important to note that the sulfate group in the structures of Series II compounds acts as a bridging group between two adjacent $\mathrm{Ln}^{3+}$ ions; hence, fewer sulfate oxygen atoms are available for $\mathrm{H}$-bonding interactions. On the other hand, both Series I and II have similar morphological features, demonstrated by aggregates of elongated platy particles (Figure S24). However, from the SEM images, Series II particles are apparently smaller than those of Series I. Smaller particles are thought to decrease proton conductivity, as observed for other compounds. ${ }^{30,65,66}$

Nafion-Mixed Membranes. Two compounds showing high proton conductivity capabilities (one from each series, namely, SD-Eu-I and Tb-II) were selected for the preparation of composite membranes using Nafion as the supporting polymeric matrix and a load of the corresponding lanthanide phosphonate of $3 \% \mathrm{w} / \mathrm{w}$ (N/SD-Eu-I and N/Tb-II). This
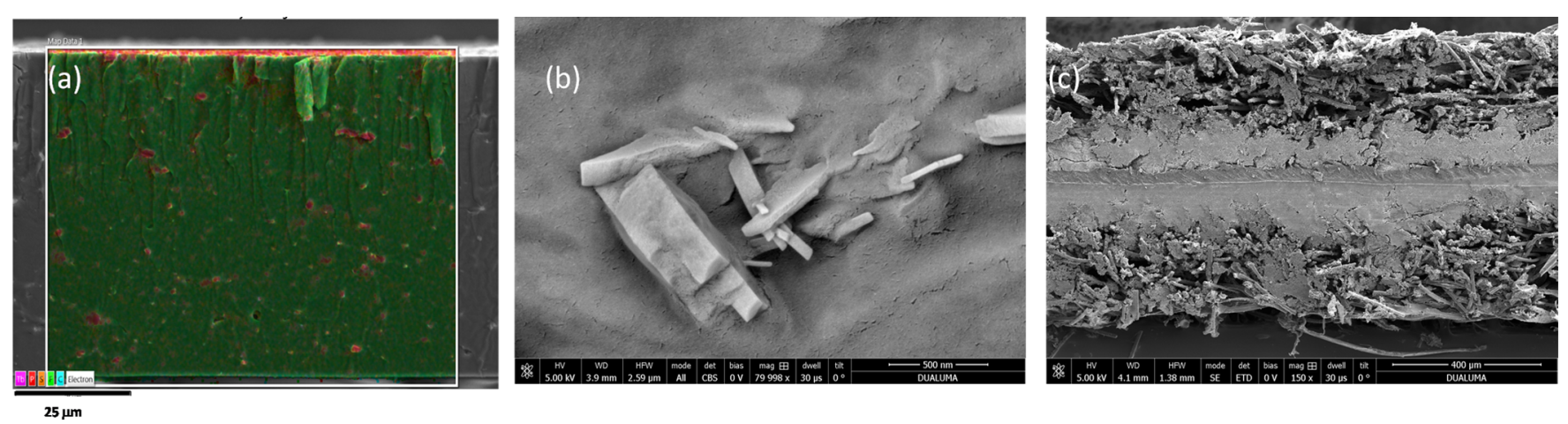

Figure 5. SEM images for N/Tb-II membrane: (a) cross-sectional SEM-EDX, (b) surface FE-SEM, and (c) cross-section of MEA after conducting the fuel cell durability test. 
percentage was previously shown as the optimal composition. $^{30}$ The powder diffraction patterns of all composite membranes display the characteristic diffraction peaks of the different crystalline lanthanide phosphonates together with the broad peak, between 12 and $20^{\circ}(2 \theta)$, typical of the pristine Nafion membrane (Figure S25). In addition, the SEM micrographs of the composite membranes in combination with EDX analysis (Figure 5a and Figure S26), confirm a uniform distribution of the metal phosphonate particles inside the polymeric matrix, especially for N/Tb-II. On a nanometer scale, the surface FE-SEM images (Figure 5b and Figure S26) display the platy morphology of lanthanide phosphonate particles forming small aggregates fairly well integrated into the Nafion matrix.

Composite membranes adsorb 14-16\% less water than pristine Nafion (Table 3), which may be attributed to the

Table 3. Proton Conductivities, Particle Sizes, and Water Uptake of Pristine Nafion and Nafion-Mixed Membranes

\begin{tabular}{lccccccc} 
& \multicolumn{2}{c}{$\begin{array}{c}\text { proton conductivity } \\
\left(\mathrm{mS} \cdot \mathrm{cm}^{-1}\right)\end{array}$} & & $\begin{array}{c}\text { particle } \\
\text { size }\end{array}$ & \\
\cline { 2 - 3 } $\begin{array}{l}\text { composite } \\
\text { membrane }\end{array}$ & $\mathbf{7 0}{ }^{\circ} \mathbf{C}$ & $\mathbf{8 0}^{\circ} \mathbf{C}$ & $\mathbf{9 0}^{\circ} \mathbf{C}$ & & Dv(50) & $\begin{array}{c}\text { water } \\
\text { uptake }\end{array}$ \\
Nafion & 34.9 & 34.9 & 34.4 & & 43.2 \\
N/SD-Eu-I & 31.9 & 34.4 & 31.4 & & 1000 & 26.5 \\
N/Tb-II & 35.4 & 36.1 & 34.3 & & 1370 & 29.5 \\
\hline
\end{tabular}

existence of a strong interaction between lanthanide phosphonate particles and the hydrophilic sulfonic groups of the organic polymer, thus limiting access of water molecules to these groups, as well as the filler particles. ${ }^{67}$ In fact, the sulfonate group binds to $\mathrm{Ln}^{3+}$ in lanthanide sulfophosphonates $^{30}$ and is chemically analogous to the strongly $\mathrm{Ln}^{3+}$ binding sulfate ligands. Taking into account that a high water uptake may reduce the mechanical properties of a membrane, its decrease in these mixed membranes make them suitable for fuel cell applications.

Nafion-mixed membranes contain metal phosphonate particles with distribution particle sizes, $D v(50)$ between $1000 \mathrm{~nm}$, SD-Eu-I, and $1370 \mathrm{~nm}$ for Tb-II (Figure S27). In situ through plane proton conductivity values are similar for all membranes (Figure 6, Table 3), although slightly higher conductivity was found for $\mathbf{N} / \mathbf{T b}$-II, likely due to its higher dispersion degree into the membrane and final particle size (Figure S27). However, all composite membranes show a small decay of the proton conductivity at $90{ }^{\circ} \mathrm{C}$ due, likely, to the loss of the optimal hydration degree of the membranes (Figure 6).

In addition, all composite membranes were evaluated, by performance analysis in $\mathrm{H}_{2} / \mathrm{O}_{2}$ single cells, as proton exchange membranes for the PEMFC. Figure 7 shows the polarization and power density curves of the N/SD-Eu-I and N/Tb-II composite membranes as well as those of the pristine Nafion membrane, as a commercial reference material. The incorporation of SD-Eu-I or Tb-II into the Nafion polymeric matrix leads to composite membranes that perform satisfactorily in PEMFCs. All composite membranes show improved electrochemical features compared to the pristine Nafion membrane (Figure 7, Table 4), especially at $70{ }^{\circ} \mathrm{C}$, reaching maximum current densities of 3601 and $3800 \mathrm{~mA} \cdot \mathrm{cm}^{-2}$ and maximum power densities of 1012 and $1008 \mathrm{~mW} \cdot \mathrm{cm}^{-2}$, for N/SD-Eu-I and N/Tb-II, respectively. At $90^{\circ} \mathrm{C}, \mathbf{N} / \mathrm{SD}-\mathrm{Eu}-\mathrm{I}$ shows similar

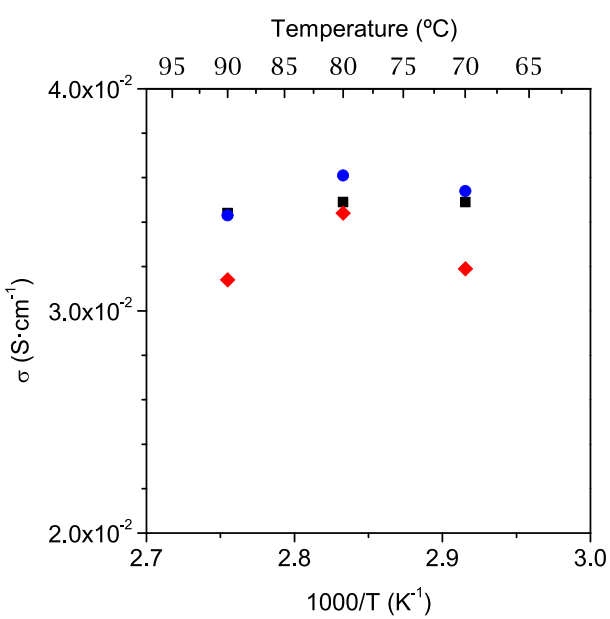

Figure 6. Proton conductivities, at $100 \% \mathrm{RH}$, for the pristine Nafion membrane (black square), N/SD-Eu-I (red diamonds), and N/Tb-II (blue circles) composite membranes.
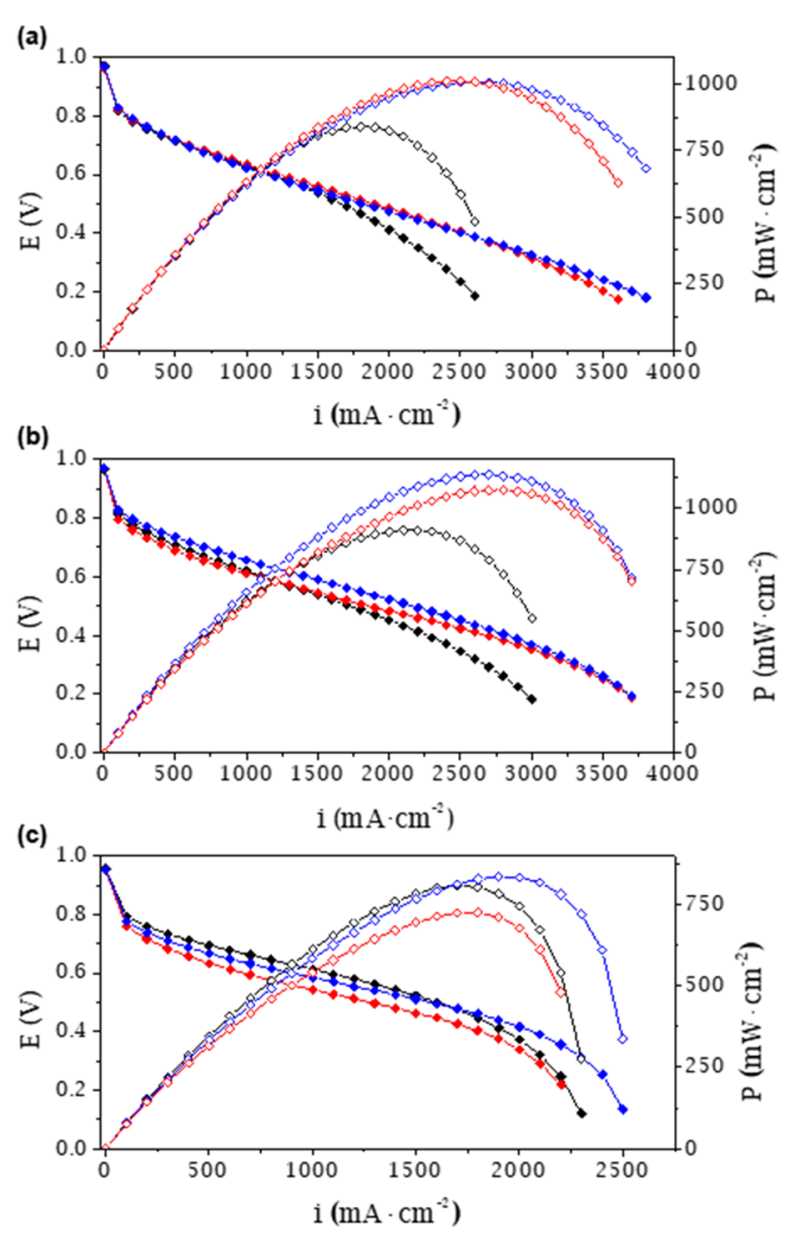

Figure 7. Polarization (full) and power density (empty) curves for pristine Nafion (black), N/SD-Eu-I (red), and N/Tb-II (blue) composite membranes at $100 \% \mathrm{RH}$ and different temperatures of (a) 70, (b) 80 , and (c) $90{ }^{\circ} \mathrm{C}$.

behavior to the pristine Nafion membrane, while the composite $\mathbf{N} / \mathbf{T b}$-II membrane gives the best results of maximum current and power densities in the entire range of the measured temperatures (Table 4). The power and current density values obtained for these composite membranes are higher than those obtained for pristine Nafion (Table 4) and, 
Table 4. Maximum Current and Power Density Values

\begin{tabular}{|c|c|c|c|c|c|c|c|c|c|}
\hline \multirow[b]{2}{*}{ membrane } & \multicolumn{3}{|c|}{ max. current density $\left(\mathrm{mA} \cdot \mathrm{cm}^{-2}\right)$} & \multicolumn{3}{|c|}{ current density $(0.5 \mathrm{~V})\left(\mathrm{mA} \cdot \mathrm{cm}^{-2}\right)$} & \multicolumn{3}{|c|}{ max. power density $\left(\mathrm{mW} \cdot \mathrm{cm}^{-2}\right)$} \\
\hline & $70^{\circ} \mathrm{C}$ & $80^{\circ} \mathrm{C}$ & $90^{\circ} \mathrm{C}$ & $70^{\circ} \mathrm{C}$ & $80^{\circ} \mathrm{C}$ & $90^{\circ} \mathrm{C}$ & $70^{\circ} \mathrm{C}$ & $80^{\circ} \mathrm{C}$ & $90^{\circ} \mathrm{C}$ \\
\hline Nafion & 2600 & 3000 & 2299 & 1699 & 1700 & 1600 & 840 & 910 & 809 \\
\hline N/SD-Eu-I & 3601 & 3700 & 2000 & 1899 & 1800 & 1299 & 1012 & 1075 & 725 \\
\hline N/Tb-II & 3800 & 3700 & 2499 & 1800 & 2100 & 1600 & 1008 & 1138 & 836 \\
\hline
\end{tabular}

to the best of our knowledge, represent the highest values reported for composite Nafion/MOF membranes. ${ }^{68-70}$

Cell lifetime is an important factor to be considered for this particular application. Therefore, to complete the electrochemical characterization of the composite membranes, durability tests were performed maintaining the operating MEAs at constant voltage $(0.5 \mathrm{~V}), 80^{\circ} \mathrm{C}$, and $100 \% \mathrm{RH}$ during, approximately, $467 \mathrm{~min}$. The current density curves recorded throughout the entire time are shown in Figure 8.

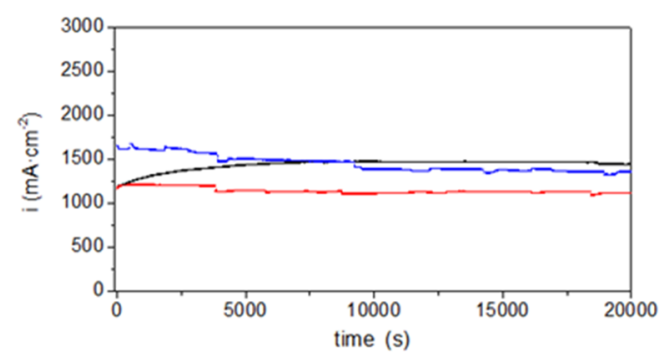

Figure 8. Current density curves through the time at constant voltage $(0.5 \mathrm{~V}), 80^{\circ} \mathrm{C}$, and $100 \% \mathrm{RH}$ for Nafion (black), N/SD-Eu-I (red), and N/Tb-II (blue).

The three MEAs perform efficiently along the entire experiment even though in the case of pristine Nafion a more stable behavior was observed from the beginning with a slight and continuous increase in the supplied current density up to around $300 \mathrm{~min}$ and then remaining practically constant afterward. At shorter times, the N/Tb-II membrane provides a somewhat higher current density than pristine Nafion although it gradually decreases over time and stabilizes posterior to 150 min. If the two composite membranes are compared, again $\mathbf{N}$ / Tb-II performs clearly better.

Once the electrochemical characterization was finished, the single cell was disassembled and the MEA was examined, verifying that its appearance was acceptable and did not present fractures, a fact that was corroborated by means of scanning electron microscopy of the cross sections (Figure 5c). Homogeneous and crack-free morphologies were observed, maintaining a good adhesion between layers so it can be concluded that the composite membranes are mechanically stable and durable under the operating conditions.

\section{CONCLUSIONS}

In this work, we have examined the incorporation of sulfate ions into the layered structure of $\mathrm{Ln}^{3+}-\mathrm{H}_{x} \mathrm{NMP}$ coordination polymers in order to evaluate their performances as proton conducting fillers in PEMFCs. From a structural point of view, sulfate acts as a charge-compensating anion or plays a role as a bridging group in the mixed layers. For the former case, the polymorph series $\left\{\mathrm{Ln}_{2}\left[\mathrm{HN}\left(\mathrm{CH}_{2}\right)_{3}\left(\mathrm{PO}_{3} \mathrm{H}\right)_{3}\right]_{2}\left(\mathrm{H}_{2} \mathrm{O}\right)_{4}\right\}$ $\left(\mathrm{HSO}_{4}\right)_{2} \cdot n \mathrm{H}_{2} \mathrm{O}(\mathrm{Ln}=\mathrm{Pr}, \mathrm{Nd}, \mathrm{Sm}, \mathrm{Eu}, \mathrm{Gd}, \mathrm{Tb}, \mathrm{Er}, \mathrm{Yb} ; n=$ 4-5; Series I) was produced. A second series of materials (Series II) was obtained by increasing the concentration of sulfuric acid in solution, giving rise to the composition $\mathrm{Ln}\left[\mathrm{HN}\left(\mathrm{CH}_{2}\right)_{3}\left(\mathrm{PO}_{3} \mathrm{H}_{2}\right)\left(\mathrm{PO}_{3} \mathrm{H}\right)_{2}\right] \mathrm{SO}_{4} \cdot 2 \mathrm{H}_{2} \mathrm{O} \quad(\mathrm{Ln}=\mathrm{Pr}, \mathrm{Nd}$, $\mathrm{Eu}, \mathrm{Gd}, \mathrm{Tb})$. The latter solids also featured layers composed of edge-sharing dimeric $\mathrm{Ln}_{2} \mathrm{O}_{14}$ polyhedra, interconnected by the bridging sulfate ligands. In contrast to the compounds of Series II, heating the compounds of Series I led to complex dynamics of transformation at high relative humidity, yielding structures characteristic of Series II, at $35{ }^{\circ} \mathrm{C}$, whereas sulfatedeficient networks was produced at $80{ }^{\circ} \mathrm{C}$. All stable materials studied exhibited enhanced proton conductivity with respect to their $\mathrm{Cl}^{-}$-containing congeners, with values ranging from $1.1 \times$ $10^{-3}$ to $3.6 \times 10^{-2} \mathrm{~S} \cdot \mathrm{cm}^{-1}$ at $80{ }^{\circ} \mathrm{C}$ and $95 \% \mathrm{RH}$. Preliminary results indicate that these solids perform satisfactorily as fillers of Nafion-based membranes, showing power and current densities higher than those of the pristine Nafion in short times. Nevertheless, the time-dependent current density curves revealed, in the case of pristine Nafion, a slightly more stable behavior, likely due to its higher water uptake capacity.

\section{ASSOCIATED CONTENT}

\section{Supporting Information}

The Supporting Information is available free of charge at https://pubs.acs.org/doi/10.1021/acsami.1c01441.

Details of $\mathrm{ab}$ initio electronic structure calculations, molecular dynamics simulation, PL spectra, Rietveld plots, representative coordination environment of $\mathrm{Ln}$ ions of Series I and II, H-bond interactions, thermal analysis, XRPD patterns, thermodiffractometric studies, complex impedance plane plots, SEM-EDX images, force field parameters, computational results, crystallographic data, and $\mathrm{H}$-bond distances (PDF)

Computed charge density (MP4)

\section{AUTHOR INFORMATION}

\section{Corresponding Authors}

Pascual Olivera-Pastor - Departamento de Química Inorgánica, Cristalografía y Mineralogía, Universidad de Málaga, Málaga 29071, Spain; 다이.org/0000-00016079-2933; Email: poliverap@uma.es

Aurelio Cabeza - Departamento de Química Inorgánica, Cristalografía y Mineralogía, Universidad de Málaga, Málaga 29071, Spain; ○orcid.org/0000-0002-1582-3240; Email: aurelio@uma.es

\section{Authors}

Inés R. Salcedo - Departamento de Química Inorgánica, Cristalografía y Mineralogía, Universidad de Málaga, Málaga 29071, Spain; 이이.org/0000-0001-9986-6805

Rosario M. P. Colodrero - Departamento de Química Inorgánica, Cristalografía y Mineralogía, Universidad de Málaga, Málaga 29071, Spain; ○ orcid.org/0000-00024318-4511

Montse Bazaga-García - Departamento de Química Inorgánica, Cristalografía y Mineralogía, Universidad de 
Málaga, Málaga 29071, Spain; 이이.org/0000-00026487-1767

M. López-González - Instituto de Ciencia y Tecnología de Polímeros (ICTP-CSIC), Madrid 28006, Spain

Carmen del Río - Instituto de Ciencia y Tecnología de Polímeros (ICTP-CSIC), Madrid 28006, Spain

Konstantinos Xanthopoulos - Crystal Engineering, Growth and Design Laboratory, Department of Chemistry, University of Crete, Heraklion GR-71003, Greece; orcid.org/00000003-3652-6816

Konstantinos D. Demadis - Crystal Engineering, Growth and Design Laboratory, Department of Chemistry, University of Crete, Heraklion GR-71003, Greece; 이이이.org/00000002-0937-8769

Gary B. Hix - School of Sciences, University of Wolverhampton, Wolverhampton WV1 1LY, United Kingdom

Aleksandra D. Furasova - Department of Physics and Engineering, ITMO University, St. Petersburg 197101, Russia

Duane Choquesillo-Lazarte - Laboratorio de Estudios Cristalográficos, IACT (CSIC-UGR), 18100 Armilla,

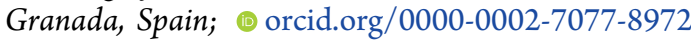

Complete contact information is available at: https://pubs.acs.org/10.1021/acsami.1c01441

\section{Author Contributions}

${ }^{\dagger}$ I.R.S. and R.M.P.C. contributed equally. The manuscript was written through contributions of all authors. All authors have given approval to the final version of the manuscript.

\section{Funding}

Financial support through the following projects is acknowledged: UMA authors for MAT2016-77648-R (MICINN/ FEDER); PID2019-110249RB-I00 (MICINN/FEDER) and Junta de Andalucia (FQM113); UoC authors for The Special Account of Research, Program INNOVAMAT KA 10694; D.C.L. for PGC2018-102047-B-I00 (MICINN/FEDER); M.L.G. for PGC2018-095364-B-I00 (MICINN/FEDER); C.R. for ENE2017-86711-C3-1-R and ENE2017-90932REDT (MICINN/FEDER). A.D.F. for the Russian Science Foundation (Grant No. 19-79-10241).

\section{Notes}

The authors declare no competing financial interest.

\section{ACKNOWLEDGMENTS}

Selected XRD experiments were performed at the BM04 beamline at the ALBA Synchrotron (proposal no 2016091873) with the collaboration of ALBA staff.

\section{REFERENCES}

(1) Kang, D. W.; Kang, M.; Hong, C. S. Post-Synthetic Modification of Porous Materials: Superprotonic Conductivities and Membrane Applications in Fuel Cells. J. Mater. Chem. A 2020, 8, 7474-7494.

(2) Kim, A. R.; Vinothkannan, M.; Song, M. H.; Lee, J.-Y.; Lee, H.K.; Yoo, D. J. Amine functionalized carbon nanotube (ACNT) filled in sulfonated poly(ether ether ketone) membrane: Effects of ACNT in improving polymer electrolyte fuel cell performance under reduced relative humidity. Composites, Part B 2020, 188, 107890.

(3) Lee, K. H.; Chu, J. Y.; Mohanraj, V.; Kim, A. R.; Song, M. H.; Yoo, D. J. Enhanced Ion Conductivity of Sulfonated Poly(Arylene Ether Sulfone) Block Coplymers Linked by Aliphatic Chains Constructing Wide-Range Ion Cluster for Proton Conducting Electrolytes. Int. J. Hydrogen Energy 2020, 45, 29297-29307.
(4) Gagliardi, G. G.; Ibrahim, A.; Borello, D.; el-Kharouf, A. Composite Polymers Development and Application for Polymer Electrolyte Membrane Technologies-A Review. Molecules 2020, 25, 1712.

(5) Rao, Z.; Feng, K.; Tang, B.; Wu, P. Construction of Well Interconnected Metal-Organic Framework Structure for Effectively Promoting Proton Conductivity of Proton Exchange Membrane. J. Membr. Sci. 2017, 533, 160-170.

(6) Donnadio, A.; Narducci, R.; Casciola, M.; Marmottini, F.; D’Amato, R.; Jazestani, M.; Chiniforoshan, H.; Costantino, F. Mixed Membrane Matrices Based On Nafion/UiO-66/ $/ \mathrm{SO}_{3} \mathrm{H}-\mathrm{UiO}-66$ NanoMofs: Revealing the Effect of Crystal Size, Sulfonation, and Filler Loading on the Mechanical and Conductivity Properties. ACS Appl. Mater. Interfaces 2017, 9, 42239-42246.

(7) Vinothkannan, M.; Ramakrishnan, S.; Kim, A. R.; Lee, H.-K.; Yoo, D. J. Ceria Stabilized by Titanium Carbide as a Sustainable Filler in the Nafion Matrix Improves the Mechanical Integrity, Electrochemical Durability, and Hydrogen Impermeability of ProtonExchange Membrane Fuel Cells: Effects of the Filler Content. ACS Appl. Mater. Interfaces 2020, 12, 5704-5716.

(8) Engel, E. R.; Scott, J. L. Advances in the green chemistry of coordination polymer materials. Green Chem. 2020, 22, 3693-3715.

(9) Horike, S.; Umeyama, D.; Kitagawa, S. Ion Conductivity and Transport by Porous Coordination Polymers and Metal-Organic Frameworks. Acc. Chem. Res. 2013, 46, 2376-2384.

(10) Su, X.; Yao, Z.; Ye, Y.; Zeng, H.; Xu, G.; Wu, L.; Ma, X.; Chen, Q. H.; Wang, L.; Zhang, Z.; Xiang, S. 40-Fold Enhanced Intrinsic Proton Conductivity in Coordination Polymers with the Same Proton-Conducting Pathway by Tuning Metal Cation Nodes. Inorg. Chem. 2016, 55, 983-986.

(11) Zhang, G.; Fei, H. Missing Metal-Linker Connectivities in a 3D Robust Sulfonate-Based Metal-Organic Framework for Enhanced Proton Conductivity. Chem. Commun. 2017, 53, 4156-4159.

(12) Gui, D.; Dai, X.; Tao, Z.; Zheng, T.; Wang, X.; Silver, M. A.; Shu, J.; Chen, L.; Wang, Y.; Zhang, T.; Xie, J.; Zou, L.; Xia, Y.; Zhang, J.; Zhang, J.; Zhao, L.; Diwu, D.; Zhou, R.; Chai, Z.; Wang, S. Unique Proton Transportation Pathway in a Robust Inorganic Coordination Polymer Leading to Intrinsically High and Sustainable Anhydrous Proton Conductivity. J. Am. Chem. Soc. 2018, 140, 6146-6155.

(13) Liu, H.; Li, R.; Lu, J.; Liu, Z.; Wang, S.; Tian, H. Proton Conduction Studies on Four Porous and Nonporous Coordination Polymers with Different Acidities and Water Uptake. CrystEngComm 2020, 22, 6935-6946.

(14) Li, R.-Y.; Liu, H.-T.; Zhou, C.-C.; Chu, Z.-T.; Lu, J.; Wang, S.N.; Jin, J.; Yan, W.-F. Ligand Substitution Induced Single-Crystal-toSingle-Crystal Transformations in Two Ni(II) Coordination Compounds Displaying Consequential Changes in Proton Conductivity. Inorg. Chem. Front. 2020, 7, 1880-1891.

(15) Shimizu, G. K. H.; Taylor, J. M.; Dawson, K. W. in Metal Phosphonate Chemistry: From Synthesis to Applications; (Eds.: Clearfield, A., Demadis, K. D.), Royal Society of Chemistry: London, 2012, Ch. 15, pp. 493-524.

(16) Bao, S.-S.; Shimizu, G. K. H.; Zheng, L.-M. Proton Conductive Metal Phosphonate Frameworks. Coord. Chem. Rev. 2019, 378, 577594.

(17) Shearan, S. J. I.; Stock, N.; Emmerling, F.; Demel, J.; Wright, P. A.; Demadis, K. D.; Vassaki, M.; Costantino, F.; Vivani, R.; Sallard, S.; Ruiz Salcedo, I.; Cabeza, A.; Taddei, M. New Directions in Metal Phosphonate and Phosphinate Chemistry. Crystals 2019, 9, 270.

(18) Lim, D. W.; Kitagawa, H. Proton Transport in Metal-Organic Frameworks. Chem. Rev. 2020, 120, 8416-8467.

(19) Bao, S. S.; Qin, M. F.; Zheng, L. M. Metal Phosphonates Incorporating Metalloligands: Assembly, Structures and Properties. Chem. Commun. 2020, 56, 12090-12108.

(20) Tholen, P.; Peeples, C. A.; Schaper, R.; Bayraktar, C.; Erkal, T. S.; Ayhan, M. M.; Çoşut, B.; Beckmann, J.; Yazaydin, A. O.; Wark, M.; Hanna, G.; Zorlu, Y.; Yücesan, G. Semiconductive Microporous Hydrogen-Bonded Organophosphonic Acid Frameworks. Nat. Commun. 2020, 11, 3180. 
(21) Ramaswamy, P.; Wong, N. E.; Gelfand, B. S.; Shimizu, G. K. H. A Water Stable Magnesium MOF that Conducts Protons Over $10^{-2} \mathrm{~S}$ $\mathrm{cm}^{-1}$. J. Am. Chem. Soc. 2015, 137, 7640-7643.

(22) Rhauderwiek, T.; Zhao, H.; Hirschle, P.; Döblinger, M.; Bueken, B.; Reinsch, H.; de Vos, D.; Wuttke, S.; Kolb, U.; Stock, N. Highly Stable and Porous Porphyrin-Based Zirconium and Hafnium Phosphonates-Electron Crystallography as an Important Tool for Structure Elucidation. Chem. Sci. 2018, 9, 5467-5478.

(23) Salcedo, I. R.; Colodrero, R. M. P.; Bazaga-García, M.; Vasileiou, A.; Papadaki, M.; Olivera-Pastor, P.; Infantes-Molina, A.; Losilla, E. R.; Mezei, G.; Cabeza, A.; Demadis, K. D. From Light to Heavy Alkali Metal Tetraphosphonates $(\mathrm{M}=\mathrm{Li}, \mathrm{Na}, \mathrm{K}, \mathrm{Rb}, \mathrm{Cs})$ : Cation Size-Induced Structural Diversity and Water-Facilitated Proton Conductivity. CrystEngComm 2018, 20, 7648-7658.

(24) Donnadio, A.; Nocchetti, M.; Costantino, F.; Taddei, M.; Casciola, M.; da Silva Lisboa, F.; Vivani, R. A Layered Mixed Zirconium Phosphate/Phosphonate with Exposed Carboxylic and Phosphonic Groups: X-Ray Powder Structure and Proton Conductivity Properties. Inorg. Chem. 2014, 53, 13220-13226.

(25) Colodrero, R. M. P.; Olivera-Pastor, P.; Losilla, E. R.; Aranda, M. A. G.; Leon-Reina, L.; Papadaki, M.; McKinlay, A. C.; Morris, R. E.; Demadis, K. D.; Cabeza, A. Multifunctional Lanthanum Tetraphosphonates: Flexible, Ultramicroporous and Proton-Conducting Hybrid Frameworks. Dalton Trans. 2012, 41, 4045-4051.

(26) Luo, H.-B.; Ren, Q.; Wang, P.; Zhang, J.; Wang, L.; Ren, X.-M. High Proton Conductivity Achieved by Encapsulation of Imidazole Molecules Into Proton-Conducting MOF-808. ACS Appl. Mater. Interfaces 2019, 11, 9164-9171.

(27) Bazaga-García, M.; Colodrero, R. M. P.; Papadaki, M.; Garczarek, P.; Zoń, J.; Olivera-Pastor, P.; Losilla, E. R.; León-Reina, L.; Aranda, M. A. G.; Choquesillo-Lazarte, D.; Demadis, K. D.; Cabeza, A. Guest Molecule-Responsive Functional Calcium Phosphonate Frameworks for Tuned Proton Conductivity. J. Am. Chem. Soc. 2014, 136, 5731-5739.

(28) Ponomareva, V. G.; Kovalenko, K. A.; Chupakhin, A. P.; Dybtsev, D. N.; Shutova, E. S.; Fedin, V. P. Imparting High Proton Conductivity to a Metal-Organic Framework Material by Controlled Acid Impregnation. J. Am. Chem. Soc. 2012, 134, 15640-15643.

(29) Xiao, C.; Wang, Y.; Chen, L.; Yin, X.; Shu, J.; Sheng, D.; Chai, Z.; Albrecht-Schmitt, T. E.; Wang, S. Boosting Proton Conductivity in Highly Robust 3D Inorganic Cationic Extended Frameworks Through Ion Exchange with Dihydrogen Phosphate Anions. Chem. - Eur. J. 2015, 21, 17591-17595.

(30) Bazaga-García, M.; Salcedo, I. R.; Colodrero, R. M. P.; Xanthopoulos, K.; Villemin, D.; Stock, N.; López-González, M.; del Río, C.; Losilla, E. R.; Cabeza, A.; Demadis, K. D.; Olivera-Pastor, P. Layered Lanthanide Sulfophosphonates and Their Proton Conduction Properties in Membrane Electrode Assemblies. Chem. Mater. 2019, 31, 9625-9634.

(31) Sharma, C. V. K.; Clearfield, A.; Cabeza, A.; Aranda, M. A. G.; Bruque, S. Deprotonation of Phosphonic Acids with $\mathrm{M}^{2+}$ Cations for the Design of Neutral Isostructural Organic-Inorganic Hybrids. J. Am. Chem. Soc. 2001, 123, 2885-2886.

(32) Silva, P.; Vieira, F.; Gomes, A. C.; Ananias, D.; Fernandes, J. A.; Bruno, S. M.; Soares, R.; Valente, A. A.; Rocha, J.; Paz, F. A. A. Thermal Transformation of a Layered Multifunctional Network into a Metal-Organic Framework Based on a Polymeric Organic Linker. J. Am. Chem. Soc. 2011, 133, 15120-15138.

(33) Bazaga-García, M.; Angeli, G. K.; Papathanasiou, K. E.; Salcedo, I. R.; Olivera-Pastor, P.; Losilla, E. R.; Choquesillo-Lazarte, D.; Hix, G. B.; Cabeza, A.; Demadis, K. D. Luminescent and Proton Conducting Lanthanide Coordination Networks Based on a Zwitterionic Tripodal Triphosphonate. Inorg. Chem. 2016, 55, 7414-7424.

(34) Mendes, R. F.; Antunes, M. M.; Silva, P.; Barbosa, P.; Figueiredo, F.; Linden, A.; Rocha, J.; Valente, A. A.; Almeida Paz, F. A. A Lamellar Coordination Polymer with Remarkable Catalytic Activity. Chem. - Eur. J. 2016, 22, 13136-13146.
(35) Mendes, R. F.; Barbosa, P.; Domingues, E. M.; Silva, P.; Figueiredo, F.; Almeida Paz, F. A. Enhanced Proton Conductivity in a Layered Coordination Polymer. Chem. Sci. 2020, 11, 6305-6311.

(36) Wahiduzzaman, M.; Wang, S.; Schnee, J.; Vimont, A.; Ortiz, V.; Yot, P. G.; Retoux, R.; Daturi, M.; Lee, J. S.; Chang, J.-S.; Serre, C.; Maurin, G.; Devautour-Vinot, S. A High Proton Conductive Hydrogen-Sulfate Decorated Titanium Carboxylate Metal-Organic Framework. ACS Sustainable Chem. Eng. 2019, 7, 5776-5783.

(37) Sheldrick, G. M. A Short History of SHELX. Acta Crystallogr., Sect. A: Found. Crystallogr. 2008, 64, 112-122.

(38) Sheldrick, G. M. Crystal Structure Refinement with SHELXL. Acta Crystallogr., Sect. C: Struct. Chem. 2015, 71, 3-8.

(39) Dolomanov, O. V.; Bourhis, L. J.; Gildea, R. J.; Howard, J. A. K.; Puschmann, H. OLEX2: A Complete Structure Solution, Refinement and Analysis Program. J. Appl. Crystallogr. 2009, 42, 339-341.

(40) Rietveld, H. M. A profile refinement method for nuclear and magnetic structures. J. Appl. Crystallogr. 1969, 2, 65-71.

(41) Mendes, R. F.; Almeida Paz, F. A. Dynamic Breathing Effect in Metal-Organic Frameworks: Reversible 2D-3D-2D-3D Single-Crystal to Single-Crystal Transformation. Inorg. Chim. Acta 2017, 460, 99107.

(42) Altomare, A.; Cuocci, C.; Giacovazzo, C.; Moliterni, A.; Rizzi, R.; Corriero, N.; Falcicchio, A. EXPO2013: A Kit of Tools for Phasing Crystal Structures From Powder Data. J. Appl. Crystallogr. 2013, 46, $1231-1235$

(43) Larson, A. C.; Von Dreele, R. B. General Structure Analysis System (GSAS); Los Alamos National Laboratory Report LAUR: 2004, 86-748.

(44) Toby, B. H. EXPGUI, A Graphical User Interface for GSAS. J. Appl. Crystallogr. 2001, 34, 210-213.

(45) Novocontrol. winDETA; Novocontrol GmbH: Hundsangen, Germany, 1995.

(46) Giannozzi, P.; Baroni, S.; Bonini, N.; Calandra, M.; Car, R.; Cavazzoni, C.; Ceresoli, D.; Chiarotti, G. L.; Cococcioni, M.; Dabo, I.; Dal Corso, A.; de Gironcoli, S.; Fabris, S.; Fratesi, G.; Gebauer, R.; Gerstmann, U.; Gougoussis, C.; Kokalj, A.; Lazzeri, M.; MartinSamos, L.; Marzari, N.; Mauri, F.; Mazzarello, R.; Paolini, S.; Pasquarello, A.; Paulatto, L.; Sbraccia, C.; Scandolo, S.; Sclauzero, G.; Seitsonen, A. P.; Smogunov, A.; Umari, P.; Wentzcovitch, R. M. QUANTUM ESPRESSO: A Modular and Open-Source Software Project for Quantum Simulations of Materials. J. Phys.: Condens. Matter 2009, 21, 395502.

(47) Giannozzi, P.; Andreussi, O.; Brumme, T.; Bunau, O.; Buongiorno Nardelli, M.; Calandra, M.; Car, R.; Cavazzoni, C.; Ceresoli, D.; Cococcioni, M.; Colonna, N.; Carnimeo, I.; Dal Corso, A.; de Gironcoli, S.; Delugas, P.; DiStasio, R. A., Jr.; Ferretti, A.; Floris, A.; Fratesi, G.; Fugallo, G.; Gebauer, R.; Gerstmann, U.; Giustino, F.; Gorni, T.; Jia, J.; Kawamura, M.; Ko, H.-Y.; Kokalj, A.; Küçükbenli, E.; Lazzeri, M.; Marsili, M.; Marzari, N.; Mauri, F.; Nguyen, N. L.; Nguyen, H.-V.; Otero-de-la-Roza, A.; Paulatto, L.; Poncé, S.; Rocca, D.; Sabatini, R.; Santra, B.; Schlipf, M.; Seitsonen, A. P.; Smogunov, A.; Timrov, I.; Thonhauser, T.; Umari, P.; Vast, N.; Wu, X.; Baroni, S. Advanced Capabilities for Materials Modelling With Quantum ESPRESSO. J. Phys.: Condens. Matter 2017, 29, 465901 .

(48) Giannozzi, P.; Baseggio, O.; Bonfâ, P.; Brunato, D.; Car, R.; Carnimeo, I.; Cavazzoni, C.; de Gironcoli, S.; Delugas, P.; Ferrari Ruffino, F.; Ferretti, A.; Marzari, N.; Timrov, I.; Urru, A.; Baroni, S. Quantum ESPRESSO Toward the Exascale. J. Chem. Phys. 2020, 152, $154105-154116$.

(49) Manz, T. A.; Limas, N. G. Introducing DDEC6 Atomic Population Analysis: Part 1. Charge Partitioning Theory and Methodology. RSC Adv. 2016, 6, 47771-47801.

(50) Limas, N. G.; Manz, T. A. Introducing DDEC6 Atomic Population Analysis: Part 2. Computed Results for A Wide Range of Periodic and Nonperiodic Materials. RSC Adv. 2016, 6, 4572745747. 
(51) Plimpton, S. Fast Parallel Algorithms for Short-Range Molecular Dynamics. J. Comput. Phys. 1995, 117, 1-19.

(52) Rappe, A. K.; Casewit, C. J.; Colwell, K. S.; Goddard, W. A., III; Skiff, W. M. UFF, A Full Periodic Table Force Field for Molecular Mechanics and Molecular Dynamics Simulations. J. Am. Chem. Soc. 1992, 114, 10024-10035.

(53) Tirado-Rives, J.; Jorgensen, W. L. Contribution of Conformer Focusing to the Uncertainty in Predicting Free Energies for ProteinLigand Binding. J. Med. Chem. 2006, 49, 5880-5884.

(54) Dodda, L. S.; Vilseck, J. Z.; Tirado-Rives, J.; Jorgensen, W. L. 1.14*CM1A-LBCC: Localized Bond-Charge Corrected CM1A Charges for Condensed-Phase Simulations. J. Phys. Chem. B 2017, 121, 3864-3870.

(55) Dodda, L. S.; Cabeza de Vaca, I.; Tirado-Rives, J.; Jorgensen, W. L. LigParGen Web Server: an Automatic OPLS-AA Parameter Generator for Organic Ligands. Nucleic Acids Res. 2017, 45, W331W336.

(56) Hanwell, M. D.; Curtis, D. E.; Lonie, D. C.; Vandermeersch, T.; Zurek, E.; Hutchison, G. R. Avogadro: an Advanced Semantic Chemical Editor, Visualization, and Analysis Platform. Aust. J. Chem. 2012, 4, 17.

(57) Frisch, M. J.; Trucks, G. W.; Schlegel, H. B.; Scuseria, G. E.; Robb, M. A.; Cheeseman, J. R.; Montgomery, J. A., Jr.; Vreven, T.; Kudin, K. N.; Burant, J. C.; Millam, J. M.; Iyengar, S. S.; Tomasi, J.; Barone, V.; Mennucci, B.; Cossi, M.; Scalmani, G.; Rega, N.; Petersson, G. A.; Nakatsuji, H.; Hada, M.; Ehara, M.; Toyota, K.; Fukuda, R.; Hasegawa, J.; Ishida, M.; Nakajima, T.; Honda, Y.; Kitao, O.; Nakai, H.; Klene, M.; Li, X.; Knox, J. E.; Hratchian, H. P.; Cross, J. B.; Bakken, V.; Adamo, C.; Jaramillo, J.; Gomperts, R.; Stratmann, R. E.; Yazyev, O.; Austin, A. J.; Cammi, R.; Pomelli, C.; Ochterski, J. W.; Ayala, P. Y.; Morokuma, K.; Voth, G. A.; Salvador, P.; Dannenberg, J. J.; Zakrzewski, V. G.; Dapprich, S.; Daniels, A. D.; Strain, M. C.; Farkas, O.; Malick, D. K.; Rabuck, A. D.; Raghavachari, K.; Foresman, J. B.; Ortiz, J. V.; Cui, Q.; Baboul, A. G.; Clifford, S.; Cioslowski, J.; Stefanov, B. B.; Liu, G.; Liashenko, A.; Piskorz, P.; Komaromi, I.; Martin, R. L.; Fox, D. J.; Keith, T.; Al-Laham, M. A.; Peng, C. Y.; Nanayakkara, A.; Challacombe, M.; Gill, P. M. W.; Johnson, B.; Chen, W.; Wong, M. W.; Gonzalez, C.; Pople, J. A. Gaussian 03, Revision C.02; Gaussian, Inc.: Wallingford CT. 2004, 6494.

(58) Zheng, S.; Tang, Q.; He, J.; Du, S.; Xu, S.; Wang, C.; Xu, Y.; Lin, F. VFFDT: A New Software for Preparing AMBER Force Field Parameters for Metal-Containing Molecular Systems. J. Chem. Inf. Model. 2016, 56, 811-818.

(59) Netzsch, P.; Bariss, H.; Bayarjargal, L.; Höppe, H. A. Tb $\left(\mathrm{HSO}_{4}\right)\left(\mathrm{SO}_{4}\right)$ - A Green Emitting Hydrogensulfate Sulfate with Second Harmonic Generation Response. Dalton Trans. 2019, 48, $16377-16383$.

(60) Deng, X.; Hu, J. Y.; Luo, J.; Liao, W. M.; He, J. Conductive Metal-Organic Frameworks: Mechanisms, Design Strategies and Recent Advances. Topics Curr Chem 2020, 378, 27.

(61) Sone, Y.; Ekdunge, P.; Simonsson, D. Proton Conductivity of Nafion 117 as Measured by a Four-Electrode AC Impedance Method. J. Electrochem. Soc. 1996, 143, 1254-1259.

(62) Del Río, C.; Morales, E.; Escribano, P. G. Nafion/Sposs Hybrid Membranes for PEMFC. Single Cell Performance and Electrochemical Characterization at Different Humidity Conditions. Int. J. Hydrogen Energy 2014, 39, 5326-5337.

(63) Taylor, J. M.; Dawson, K. W.; Shimizu, G. K. H. A Water-Stable Metal-Organic Framework with Highly Acidic Pores for ProtonConducting Applications. J. Am. Chem. Soc. 2013, 135, 1193-1196.

(64) Xing, X.-S.; Fu, Z.-H.; Zhang, N.-N.; Yu, X.-Q.; Wang, M.-S.; Guo, G.-C. High Proton Conduction in an Excellent Water-Stable Gadolinium Metal-Organic Framework. Chem. Commun. 2019, 55, 1241-1244.

(65) Wong, N. E.; Ramaswamy, P.; Lee, A. S.; Gelfand, B. S.; Bladek, K. J.; Taylor, J. M.; Spasyuk, D. M.; Shimizu, G. K. H. Tuning Intrinsic and Extrinsic Proton Conduction in Metal-Organic Frameworks by the Lanthanide Contraction. J. Am. Chem. Soc. 2017, 139, 14676-14683.
(66) Levenson, D. A.; Zhang, J.; Gelfand, B. S.; Kammampata, S. P.; Thangadurai, V.; Shimizu, G. K. H. Particle Size Dependence of Proton Conduction in a Cationic Lanthanum Phosphonate MOF. Dalton Trans. 2020, 49, 4022-4029.

(67) Guo, X.; Fan, Y.; Xu, J.; Wang, L.; Zheng, J. Amino-MIL-53 (Al)-Nanosheets@ Nafion Composite Membranes with Improved Proton/Methanol Selectivity for Passive Direct Methanol Fuel Cells. Ind. Eng. Chem. Res. 2020, 59, 14825-14833.

(68) Sun, S.; Ling, L.; Xiong, Y.; Zhang, Y.; Li, Z. Trifluoromethanesulfonimide-Based Hygroscopic Semi-Interpenetrating Polymer Network for Enhanced Proton Conductivity of Nafion-Based Proton Exchange Membranes at Low Humidity. J. Membr. Sci. 2020, 612, 118339.

(69) Tsai, C.-H.; Wang, C.-C.; Chang, C.-Y.; Lin, C.-H.; Chen-Yang, Y. W. Enhancing Performance of Nafion ${ }^{\circledR}$-Based PEMFC by 1-D Channel Metal-Organic Frameworks as PEM Filler. Int. J. Hydrogen Energy 2014, 39, 15696-15705.

(70) Teixeira, F. C.; de Sá, A. I.; Teixeira, A. P. S.; Ortiz-Martínez, V. M.; Ortiz, A.; Ortiz, I.; Rangel, C. M. New Modified NafionBisphosphonic Acid Composite Membranes for Enhanced Proton Conductivity and PEMFC Performance. Int. J. Hydrogen Energy 2020, DOI: $10.1016 /$ j.ijhydene.2020.01.212.. 